\title{
e-Supply Chain Management: review, implications and directions for future research
}

\author{
Cristina Giménez \\ Dpt. of Operations and Innovation Management \\ ESADE Business School-Universitat Ramon Llull \\ Avda. de Pedralbes 60-62; 08034-Barcelona, Spain \\ cristina.gimenez@esade.edu

\section{Helena R. Lourenço} \\ GREL-IET, Department of Economics \& Business, \\ Universitat Pompeu Fabra \\ Ramon Trias Fargas, 25-27; 08005-Barcelona, Spain \\ helena.ramalhinho@upf.edu
}




\title{
e-Supply Chain Management: review, implications and directions for future research
}

\begin{abstract}
Purpose - This paper analyses the interaction of two topics: Supply Chain Management (SCM) and the Internet. Merging these two fields is a key area of concern for contemporary managers and researchers. They have realised that the Internet can enhance SCM by making real time information available and enabling collaboration between trading partners.

Design/methodology/approach - A literature review in prestigious academic journals in Operations Management and Logistics has been conducted for the period 1995-2005. The objective is to collect, organise and synthesise existing knowledge relating to SCM and the Internet.

Findings - Our study has described the impact that the Internet has on the different processes that SCM embrace. The literature review undertaken on the topic has shown that e-SCM has been acknowledged as an outstanding topic in the supply chain literature in the most prestigious Operations Management and Logistics journals, especially after year 2000. The main topics have been e-procurement, e-fulfilment and information flows.

Originality/value - The value of this paper is to define e-SCM, to analyse how research in this area has evolved during the period 1995-2005 and to identify some lines of further research.
\end{abstract}

Keywords - e-Supply Chain Management, Internet, e-SCM

Paper type - Literature review 


\section{Introduction}

Enhanced competitiveness requires that companies ceaselessly integrate within a network of organisations. Firms ignoring this challenge are destined to fall behind their rivals. This integration of companies within a network has led to put more emphasis on Supply Chain Management (SCM). "SCM is the management of upstream and downstream relationships in order to deliver superior customer value at less cost to the supply chain as a whole" (Christopher 1998). The integral value of the SCM philosophy is that "total performance of the entire supply chain is enhanced when we simultaneously optimise all the links in the chain as compared to the resulting total performance when each individual link is separately optimised (Burke and Vakkaria 2002).

In order to achieve this coordination/integration of all the links in the supply chain, information is critical. Recent technological developments in information systems and information technologies have the potential to facilitate this coordination, and this, in turn, allows the virtual integration of the entire supply chain. The focus of this integration in the context of Internet-enabled activities is generally referred to as e-SCM. Merging these two fields (SCM and the Internet) is a key area of concern for contemporary managers and researchers. Managers have realised that the Internet can enhance SCM decision making by providing real-time information and enabling collaboration between trading partners. Many companies have implemented point-of-sales scanners, which read, on real time, what is being sold. These companies do not only collect information on real-time to make decisions about what to order or how to replenish the stores; they also send this information, through the Internet, to their suppliers in order to make them able to synchronise their production to actual sales.

The recent proliferation of papers on SCM and the Internet related topics explain the increasing interest of researchers for this area. There is a growing stream of literature attempting to better understand the impact of the Internet on different SCM activities (planning, distribution, design, etc.). However, there is a disjointed scattering of research activity that fails to clearly represent what should be understood by e-SCM, what we currently know about the effects of the Internet on SCM and what we still need to learn.

Many researchers have examined the work done in the field of Operations Management and SCM, see for example (Prasad and Babbar 2000) and (Pannirselvam, Ferguson et al. 1999). Although this type of papers is very useful to give insights on research directions, we have found so far only two literature reviews on the e-SCM topic: (Johnson and Whang 2002) and (Gunasekaran and Ngai 2004). Our paper follows the same methodology as these two papers, but it differs from them in the framework used to classify the papers. (Johnson and Whang 2002) classified the papers into three categories: e-commerce, eprocurement and e-collaboration. (Gunasekaran and Ngai 2004) classified the papers according to what they called the major components of IT-enabled SCM: strategic planning for IT in SCM, virtual enterprise and SCM, e-commerce and SCM, infrastructure for IT in SCM, Knowledge and IT management in SCM, and implementation of IT in SCM. The main objective in this paper is to identify the major issues surrounding the impact of the Internet on SCM, using a classification scheme and developing a framework based on the idea that SCM is the management of supply chain processes. As (Croom 2005) pointed out very recently, there is some debate about the scope of SCM. (Oliver and Webber 1992) and (Houlihan 1984) used the term SCM for the internal supply chain that 
integrates business functions involved in the flow of materials and information from inbound to outbound ends of the business (Harland 1996). (Ellram 1991) viewed SCM as an alternative to vertical integration. (Christopher 1998) defined SCM as the management of upstream and downstream relationships. (Croom 2005) suggested that one way of dealing with the diversity of SCM definitions is to concentrate on the core processes and functions relating to the management of supply chains (for example, fulfilment, operations planning and procurement). As he points out this is not an exhaustive approach but it can provide sufficient scope for an analysis of the key initiatives being undertaken by organisations in their SCM (Croom 2005).

In the literature there is a diversity of models suggesting which are the main supply chain processes. For example, in 1996 the Supply Chain Operations Reference (SCOR) model was developed with the aim of helping organisations to improve their supply chain efficiency. This model focuses on five key processes for supply chains: plan, source, make, deliver, and return. In 1997, (Cooper, Lambert et al. 1997) defined SCM taking into account the eight supply chain processes identified by the International Centre for Competitive Excellence (now named Global Supply Chain Forum): customer relationship management, customer service management, demand management, e-fulfilment, eprocurement, manufacturing flow management, product development and commercialisation, and reverse logistics. (Hewitt 1994) found that executives identify up to fourteen business processes. As a result, we decided to adopt the (Cooper, Lambert et al. 1997) model as it provides more detailed analysis.

Given the importance of e-SCM and its impact on research and business, our motivation is to provide a literature review in a similar way as it has been done by the previous cited authors. The main objective of the present work is to provide practitioners and academicians with a comprehensive source of information to draw from, and help them identifying areas and directions for future work.

The aim of this research is to consolidate the existing research efforts concerning the impact of the Internet on SCM, and to identify promising areas for study. In particular, the objectives of this study are:

1. To define what can be understood by e-SCM.

2. To determine if e-SCM has been acknowledged as an outstanding topic in the most prestigious Operations Management and Logistics journals.

3. To identify the main topics of e-SCM during the period 1995-2003.

4. To identify the methodologies used in the existing literature.

5. To present a literature review of the main topics on e-SCM.

6. To identify implications and directions for future research.

The work is organised as follows, in section 2 we present a definition of e-SCM. In section 3 , we provide a description of the research methodology followed in this work. In section 4 , we present a summary of the research results. In section 5, for each e-SCM topic, we provide a literature review and some directions for future research. And, finally, in section 6 we present some conclusions. 


\section{Defining e-SCM}

As (Croom 2005) pointed out very recently, there is some debate about the scope of SCM. For example, (Oliver and Webber 1992) and (Houlihan 1984) used the term SCM for the internal supply chain that integrates business functions involved in the flow of materials and information from inbound to outbound ends of the business. (Ellram 1991) viewed SCM as an alternative to vertical integration. And, (Christopher 1998) defined SCM as the management of upstream and downstream relationships. (Croom 2005) suggested that one way of dealing with the diversity of SCM definitions is to concentrate on the core processes and functions relating to the management of supply chains (for example, fulfilment, operations planning and procurement).

In the literature there is a diversity of models suggesting which are the main supply chain processes. For example, the Supply Chain Operations Reference (SCOR) model developed in 1996 focuses on five key processes: plan, source, make, deliver, and return. (Cooper, Lambert et al. 1997) defined SCM taking into account the eight supply chain processes identified by the International Centre for Competitive Excellence (now named Global Supply Chain Forum): customer relationship management, customer service management, demand management, fulfilment, procurement, manufacturing flow management, product development and commercialisation, and reverse logistics.

Hewitt (1994) found that executives identify up to fourteen business processes. As a result, a definition comprising a number of processes closer to fourteen might provide more detailed information for practitioners and researchers. Accordingly, from the two previous models we decided to adopt the definition of SCM provided by (Cooper, Lambert et al. 1997). This definition has been widely referred to (see for example, (Romano and Vinelli 2001), (Cagliano, Caniato et al. 2003), (Mills, Schmitz et al. 2004), (Cousins 2005) and (Danese, Romano et al. 2006)).

(Cooper, Lambert et al. 1997) defined SCM as "the integration of key business processes from end user through original suppliers that provides products, services, and information that add value for customers and other stakeholders”. SCM ideally embraces all business processes cutting across all organisations within the supply chain, from initial point of supply to the ultimate point of consumption (Cooper, Lambert et al. 1997). For (Cooper, Lambert et al. 1997), SCM embraces the business processes identified by the International Centre for Competitive Excellence (now Global Supply Chain Forum) (see Figure 1). Accordingly, we define e-SCM as the impact that the Internet has on the integration of key business processes from end user through original suppliers that provides products, services, and information that add value for customers and other stakeholders.

The Internet can have three main impacts on the supply chain. One of the most covered

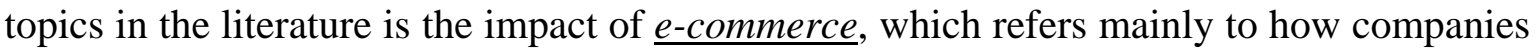
can respond to the challenges posed by the Internet on the fulfilment of goods sold through the net. Another impact refers to information sharing, how the Internet can be used as a medium to access and transmit information among supply chain partners. However, the Internet not only enables supply chain partners to access and share information, but also to access data analysis and modelling to jointly make a better planning and decision making. 
This jointly planning and decision making is the third type of impact of the Internet on SCM and we refer to it as knowledge sharing ${ }^{1}$.

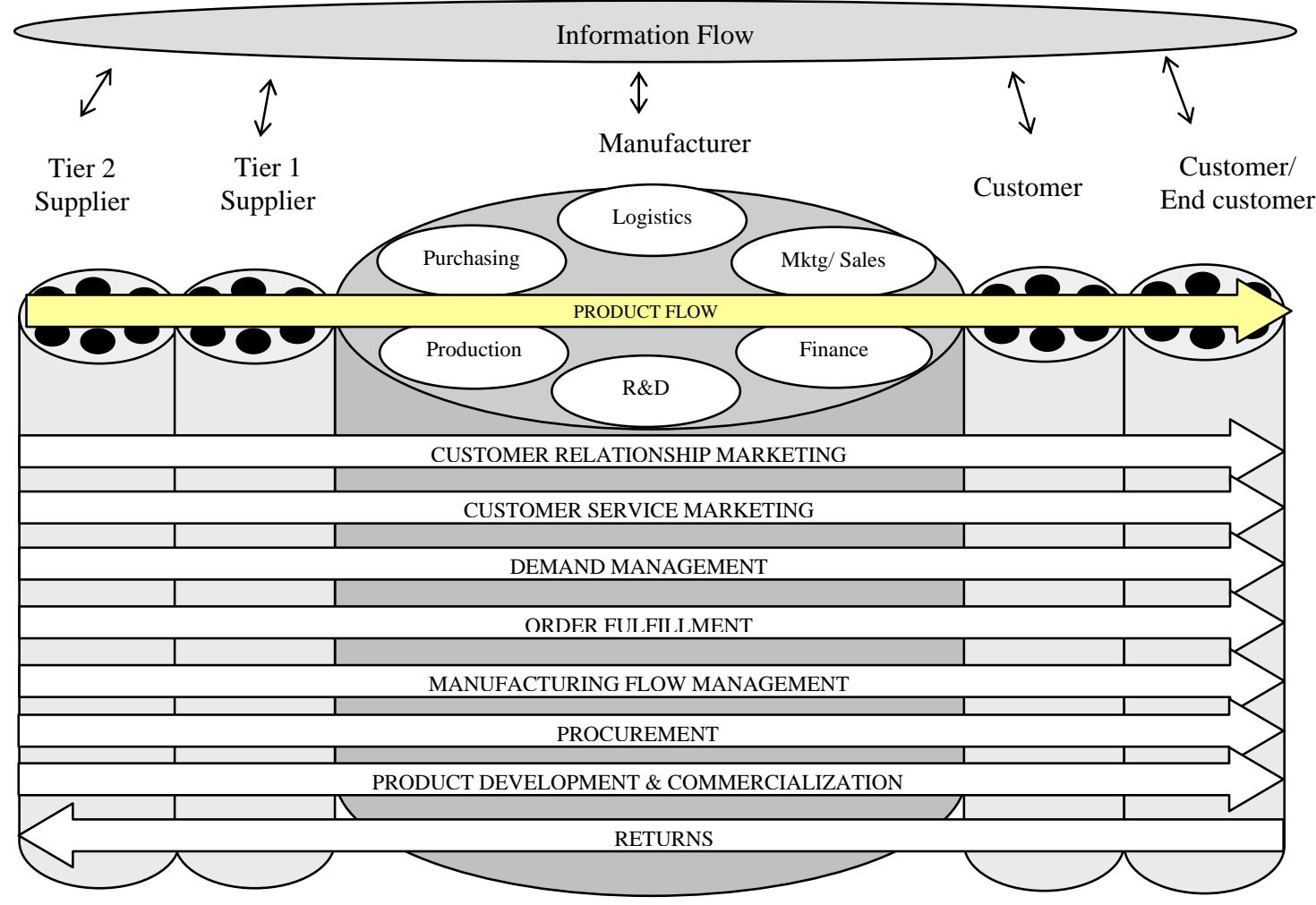

Figure 1. Supply Chain Management

Source: (Cooper, Lambert et al. 1997)

\section{Research methodology}

\subsection{Journals chosen}

This paper reviews the literature in academic journals where Operations Management and Logistics academics and practitioners publish. The objective is to collect, organise and synthesise existing knowledge relating to SCM and the Internet. We have made a literature review of thirteen Operations Management and seven Logistics journals for the period 1995-2005. Operations Management journals have been chosen through the analysis of previous studies that classified and ranked the most significant Operations Management journals in both U.S. and Europe ((Vokurka 1996); (Goh, Holsapple et al. 1997); (Soteriou, Hadjinicola et al. 1999); (Donohue and Fox 2000) and (Vastag and Montabon 2002)). The thirteen Operations Management journals selected are: California Management Review (CMR), Decision Sciences (DS), European Journal of Operational Research (EJOR), Harvard Business Review (HBR), Interfaces (INTERFACES), International Journal of Operations and Production Management (IJOPM), International Journal of Production Economics (IJPE), International Journal of Production Research (IJPR), Journal of

\footnotetext{
${ }^{1}$ In the Information Systems area the result of applying analysis, interpretation and modelling to information is known as knowledge
} 
Operations Management (JOM), Management Science (MS), Omega (OMEGA), Operations Research (OR) and Production and Operations Management (POM). Logistics journals have been chosen analyzing the reference list of Operations Management and Logistics articles; the most cited Logistics journals have been included in our analysis. These journals are: International Journal of Physical Distribution and Logistics Management (IJPDLM), Journal of Business Logistics (JBL), Journal of Enterprise Information Management (JEIM), Journal of Purchasing and Supply Management (JPSM), Journal of Supply Chain Management (JSCM), Supply Chain Management: An International Journal (SCM) and The International Journal of Logistics Management (TIJLM).

We started our analysis in 1995 because a taxonomy analysis carried out by (Alfaro, Alvarez et al. 2002) permitted to determine that in 1995 just only about $2 \%$ of published papers in prestigious Operations Management journals were dedicated to SCM. Also, the Internet is a recent information technology. As a result, the research dedicated to SCM and the Internet before 1995 must be very limited. Due to the existence of multiple words related to the topic, we spent substantial time in the traditional and electronic library system sorting through the academic and business journals reviewing titles, abstracts and manuscripts. The topics we used to search were: Internet, e-commerce, B2B, B2C, e-SCM, electronic supply chain and information technologies. In total we collected 174 articles.

\subsection{Classification methodology}

We classified the articles by topic areas and by research methodologies. In order to classify the papers by topic we developed a framework which is shown in figure 2. As previously stated, following the definition of (Cooper, Lambert et al. 1997), e-SCM is defined as the impact that the Internet has on the integration of key business processes from end user through original suppliers that provides products, services, and information that add value for customers and other stakeholders. As a result, a set of topics are related to the processes proposed by (Cooper, Lambert et al. 1997): customer relationship management, customer service management, demand management, e-fulfilment, e-procurement, manufacturing flow management, product development and commercialisation, and reverse logistics. These set of topics are represented in Figure 2 under the concept of SCM processes.

We added some topics that are related with SCM enablers, such as supply chain relationships, planning and optimisation tools and information flows. The topic of supply chain relationships was used to classify the papers that analyse the impact of the Internet on the management of supply chain relationships. The papers classified under the planning and optimisation topic are the ones that apply planning and optimisation systems based on decision models and technologies to several SCM processes. And, information flows comprises the papers that describe how information flows along the supply chain by means of Internet technologies.

Finally, we added two topics: industry structure and competitive challenges, and impact on performance. The first refers to the impact of the Internet on the industry structure and how companies are responding to competitive challenges using the Internet, and the latter refers to the impact of e-SCM on performance. In section 5, we describe in detail each topic. 


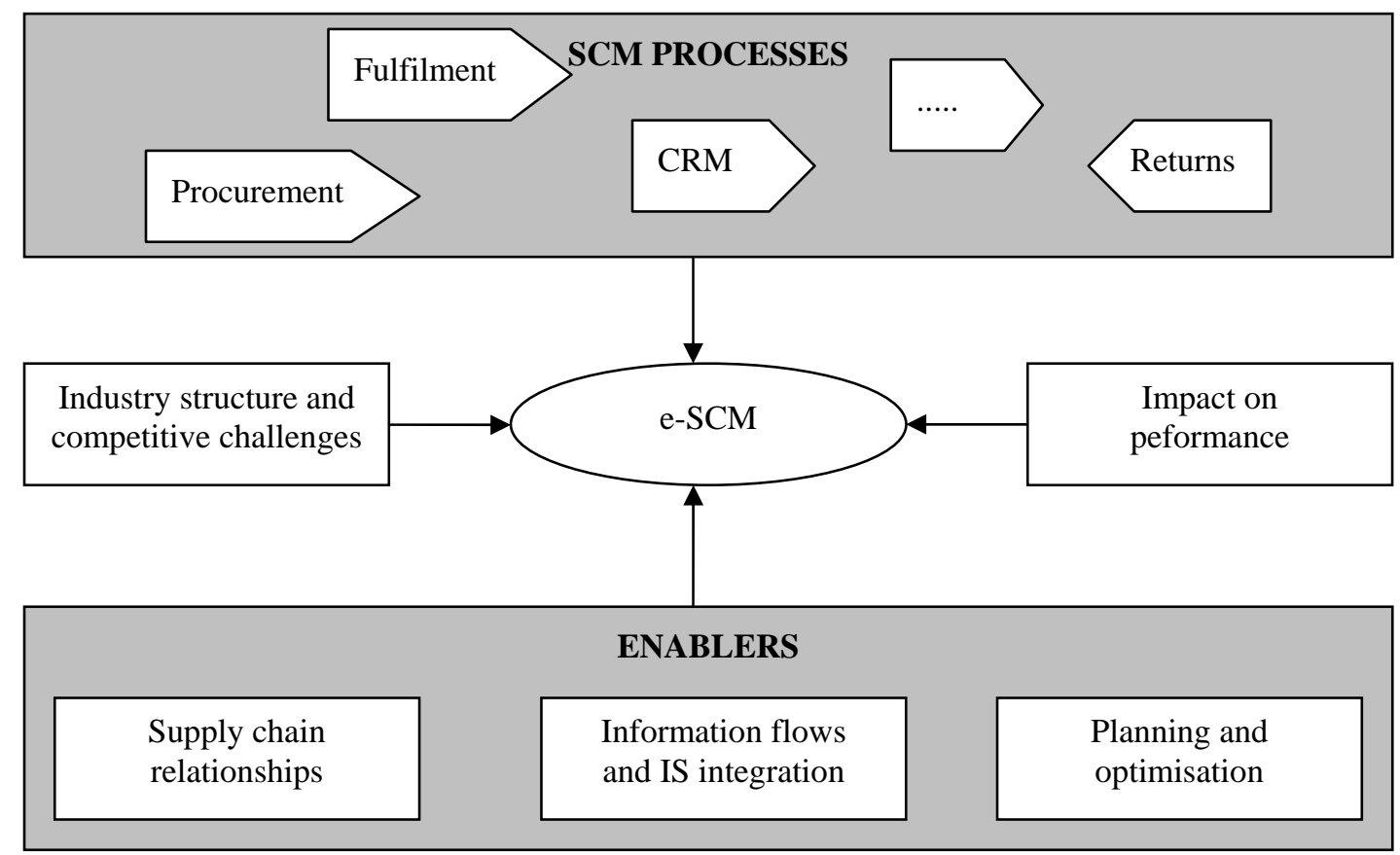

Figure 2. A framework for e-SCM

In order to classify the papers according to the methodology, we used four categories: conceptual, literature review, empirical and decision models. In the conceptual category we classified all papers that describe or present an aspect of e-SCM. In the literature review category we classified the papers whose main objective was to present a review of the work done on a specific topic. In the empirical category we considered the papers based on the results of case studies, surveys or web scans. And, finally, in the decision models category we classified all papers that apply decision technologies, such as mathematical and optimisation models, exact and heuristic solution methods, simulation, economic models, game theory, etc., to help managers to make better decisions.

In order to classify the papers and minimise questions in this process, we listed the possible subtopics by topic. However, we still found some papers whose classification was not easy. In these cases, all the authors were conferred and discrepancies were discussed until a consensus was reached.

When we were addressing the classification according to the methodology used in each paper, we realised that researchers sometimes use more than one methodology. In these cases, we identified all the methods and tried to determine the main contribution of each one to the achievement of the objective of the paper. We, therefore, classified the paper in the methodology category according to the methodology that contributed most to the objective of the paper. For example, one of the papers developed a web dynamic Available-To-Promise system and tested it in a case study. This paper was classified in the decision models category because the main objective of the paper was to develop the system. 


\section{Research results}

In this section we analyse the information obtained and provide answers to the following research questions: 1) Has e-SCM been acknowledged as an outstanding topic in the literature in the most prestigious journals of Operations Management and Logistics? 2) Which are the e-SCM topics covered in the most prestigious journals of Operations Management and Logistics? and 3) Which is the methodological profile followed by the eSCM papers published in the most prestigious Operations Management and Logistics journals? In section 5, for each e-SCM topic we present a literature review and identify some lines of further research.

\subsection{Has e-SCM been acknowledged as an outstanding topic in the literature in the most prestigious journals of Operations Management and Logistics?}

Table I shows the distribution of articles along the time and the journals. As it can be appreciated in Table I, the total number of papers related to e-SCM topics in the Operations Management and Logistics journals has increased considerably. In the 19951999 period, there were only twelve articles while after the year 1999 the number of papers published by year increased considerably. Only in one year (2000) the number of papers published was similar to the number of papers published during the previous five-year period (1995-1999). And, during the last three years of the period analysed (2003 to 2005) more than thirty papers per year have been published. The increase in the number of eSCM papers has been bigger in the Operations Management journals than in the Logistics journals. This demonstrates that the e-SCM topic has gained importance in the research agenda, especially in the Operations Management journals. From the twelve articles published during the first period (1995-1999), there are only two papers published in 1995 and three papers published during the year 1996. This suggests that the starting year of the interval object of our research (1995) can be justified.

For each journal, Table I shows the total number of papers related to the e-SCM topics in absolute and relative terms. In absolute terms the journals with a highest number of e-SCM papers published are: SCM, IJPDLM and MS. In relative terms (approximate percentage of e-SCM papers over the total number of papers published), the journals with a highest percentage are, as expected, some Logistics journals: SCM, JSCM, IJPDLM and JPSM. It has also to be pointed out that the rest of the Logistics journals have a higher percentage than most of the Operations Management journals. Only CMR and POM have a higher percentage than the Logistics journals with the lowest scores (JBL, JEIM and TIJLM). 
Table I. Articles per journal

\begin{tabular}{|c|c|c|c|c|c|c|c|c|c|}
\hline Journal & $\begin{array}{c}1995- \\
1999 \\
\end{array}$ & 2000 & 2001 & 2002 & 2003 & 2004 & 2005 & $\begin{array}{c}\text { Total } \\
\text { papers }\end{array}$ & $\begin{array}{c}\text { \% over total } \\
\text { papers }\end{array}$ \\
\hline \multicolumn{10}{|c|}{ OM/OR JOURNALS } \\
\hline CMR & 1 & 1 & & 2 & 1 & 1 & 3 & 9 & $2,76 \%$ \\
\hline DS & & & & 1 & & & 2 & 3 & $0,81 \%$ \\
\hline EJOR & & & & & 2 & 5 & 5 & 12 & $0,27 \%$ \\
\hline HBR & 1 & 2 & & & & & & 3 & $0,37 \%$ \\
\hline INTERFACES & & & 4 & 1 & 2 & & 1 & 8 & $1,47 \%$ \\
\hline IJOPM & 1 & & 2 & & 3 & 2 & 3 & 11 & $1,35 \%$ \\
\hline IJPE & & & & 6 & 2 & 4 & & 12 & $0,73 \%$ \\
\hline IJPR & & 1 & 2 & & 4 & 1 & 2 & 10 & $0,41 \%$ \\
\hline JOM & 1 & & & 2 & 1 & 1 & 2 & 7 & $1,88 \%$ \\
\hline MS & & 1 & & 1 & 6 & 2 & 7 & 17 & $1,25 \%$ \\
\hline OMEGA & & & & & 1 & 1 & & 2 & $0,46 \%$ \\
\hline OR & & & & & & & & $\mathbf{0}$ & $0,00 \%$ \\
\hline POM & & & & 4 & & 3 & & 7 & $3,10 \%$ \\
\hline TOTAL OM & 4 & 5 & 8 & 17 & 22 & 20 & 25 & 101 & \\
\hline \multicolumn{10}{|c|}{ LOGISTICS JOURNALS } \\
\hline IJPDLM & 2 & 3 & 4 & 4 & 1 & 2 & 1 & 17 & $3,80 \%$ \\
\hline JBL & & & & & 2 & 1 & 2 & 5 & $2,09 \%$ \\
\hline JEIM (LIM) & & & 1 & & 3 & 4 & 2 & 10 & $2,46 \%$ \\
\hline JSCM & & 1 & 2 & 1 & & 1 & 2 & 7 & $4,70 \%$ \\
\hline JPSM (EJPSM) & 2 & & & 2 & 1 & 2 & 1 & 8 & $3,64 \%$ \\
\hline SCM & 2 & 1 & 3 & 3 & 3 & 4 & 6 & 22 & $7,64 \%$ \\
\hline TIJLM & 2 & 1 & & & & 1 & & 4 & $2,34 \%$ \\
\hline TOTAL LOG. & 8 & 6 & 10 & 10 & 10 & 15 & 14 & 73 & \\
\hline TOTAL & 12 & 11 & 18 & 27 & 32 & 35 & 39 & 174 & \\
\hline
\end{tabular}

4.2. Which are the e-SCM topics covered in the most prestigious journals of Operations Management and Logistics?

Table II shows the topics used to classify the articles and the number of papers published on each one. As it can be appreciated in this table, the topics more covered by the existing literature are: e-procurement, e-fulfilment and information flows. The topics least covered are: demand management, customer relationship management, customer service 
management, and returns and reverse logistics. If we had included Marketing journals in our analysis we would probably have found a higher number of papers under the demand management, customer relationship management and customer service management topics. What is surprising is the reduced number of papers covering the impact of the Internet on the returns and reverse logistics process despite the increasing importance of this process. However it must be pointed out that the papers on the impact of the Internet on the reverse logistics are quite recent. We expect to find more papers covering this topic on the future. Other processes that require further study are the manufacturing flow and the product development processes, as they have also been covered by few papers. Nine papers have analysed the impact of the Internet on several supply chain processes and we expect a higher number of papers under this topic in the near future. Regarding the impact of the Internet on the performance and the industry structure, few papers have considered these topics and most of the existing papers on this topic have been published very recently.

Table II. Taxonomy analysis

\begin{tabular}{|c|c|c|c|c|c|c|c|c|}
\hline TOPIC & $\begin{array}{c}\text { Total number } \\
\text { of papers }\end{array}$ & 1995-1999 & 2000 & 2001 & 2002 & 2003 & 2004 & 2005 \\
\hline Customer relationship management & 4 & & 1 & & 1 & & 2 & \\
\hline Customer service management & 3 & & & & 1 & 2 & & \\
\hline Demand management & 1 & 1 & & & & & & \\
\hline e-fulfilment & 28 & 1 & 1 & 5 & 3 & 7 & 3 & 8 \\
\hline Manufacturing flow management & 6 & & & 3 & & 1 & 2 & \\
\hline e-procurement & 52 & 3 & 6 & 2 & 8 & 12 & 11 & 10 \\
\hline $\begin{array}{l}\text { Product development and } \\
\text { commercialization }\end{array}$ & 7 & 1 & 2 & 1 & & 2 & & 1 \\
\hline Reverse logistics and returns & 4 & & & & & 2 & 2 & \\
\hline Several supply chain processes & 9 & & & & 2 & 1 & 3 & 3 \\
\hline Supply chain relationships & 11 & 1 & & 2 & 3 & 1 & 1 & 3 \\
\hline Information flows & 28 & 4 & & 1 & 6 & 1 & 7 & 9 \\
\hline Planning \& optimisation & 7 & & & 4 & 1 & 2 & & \\
\hline $\begin{array}{l}\text { Industry structure and competitive } \\
\text { challenges }\end{array}$ & 7 & 1 & 1 & & & & 2 & 3 \\
\hline Impact on performance & 7 & & & & 2 & 1 & 2 & 2 \\
\hline Total & 174 & 12 & 11 & 18 & 27 & 32 & 35 & 39 \\
\hline
\end{tabular}

In section 5, we provide the list of papers classified under each topic.

\subsection{Which is the methodological profile followed by the e-SCM papers published in the most prestigious Operations Management and Logistics journals?}

Table III shows the research methodologies used in the papers contained in our database. The methodologies most used by the existing papers are empirical (surveys and case 
studies), decision models and conceptual. Each one of these methodologies was used approximately by one third of the papers. Only seven out of the 174 papers analysed conducted a literature review and only two of them focused on the impact of the Internet on SCM. This highlights the need of a study like the one we provide in this paper, as it tries to clearly represent what we currently know about the effects of the Internet on SCM and what we still need to learn.

The conceptual methodology has been used in almost all the topics. The literature review methodology has been used to analyse e-procurement, product development, several supply chain processes simultaneously, and planning and optimisation. All the topics, except demand management, and planning and optimisation have been analysed through an empirical methodology. Decision models have also been used in most of the topics (the topics not covered by this methodology have been the industry structure and the ones more related with the Marketing area: customer relationship management, customer service management and demand management). In section 5 , for each topic we provide an analysis of the methodologies used and identify further lines of research.

Table III. Research methodology

\begin{tabular}{|c|c|c|c|c|c|c|c|}
\hline \multirow[t]{2}{*}{ TOPIC } & \multirow{2}{*}{$\begin{array}{l}\text { Conceptual } \\
\text { and } \\
\text { frameworks }\end{array}$} & \multirow{2}{*}{$\begin{array}{l}\text { Literature } \\
\text { Review }\end{array}$} & \multicolumn{3}{|c|}{ Empirical } & \multirow{2}{*}{$\begin{array}{c}\text { Decision } \\
\text { Models }\end{array}$} & \multirow[b]{2}{*}{ Total } \\
\hline & & & $\begin{array}{l}\text { Case } \\
\text { Study }\end{array}$ & Survey & $\begin{array}{l}\text { Web } \\
\text { scan }\end{array}$ & & \\
\hline $\begin{array}{l}\text { Customer relationship } \\
\text { management }\end{array}$ & 2 & & 1 & 1 & & & 4 \\
\hline $\begin{array}{l}\text { Customer service } \\
\text { management }\end{array}$ & & & 1 & 1 & 1 & & 3 \\
\hline Demand management & 1 & & & & & & 1 \\
\hline e-fulfilment & 5 & & 2 & 8 & 2 & 11 & 28 \\
\hline $\begin{array}{l}\text { Manufacturing flow } \\
\text { management }\end{array}$ & 2 & & 1 & & & 3 & 6 \\
\hline e-procurement & 16 & 3 & 2 & 10 & 1 & 20 & 52 \\
\hline $\begin{array}{l}\text { Product development and } \\
\text { commercialization }\end{array}$ & 1 & 1 & 2 & & & 3 & 7 \\
\hline Reverse logistics and returns & & & 1 & & & 3 & 4 \\
\hline $\begin{array}{l}\text { Several supply chain } \\
\text { processes }\end{array}$ & 2 & 2 & 2 & 2 & & 1 & 9 \\
\hline Supply chain relationships & 6 & & 3 & 1 & & 1 & 11 \\
\hline Information flows & 9 & & 10 & 4 & & 5 & 28 \\
\hline Planning \& optimisation & 3 & 1 & & & & 3 & 7 \\
\hline $\begin{array}{l}\text { Industry structure and } \\
\text { competitive challenges }\end{array}$ & 3 & & 4 & & & & 7 \\
\hline Impact on performance & & & 1 & 5 & & 1 & 7 \\
\hline Total & 50 & 7 & 30 & 32 & 4 & 51 & 174 \\
\hline
\end{tabular}

In the appendix, we provide a table showing which methodology was followed by each paper. 


\section{Literature review and classification}

In this section, for each one of the topics used to classify the papers we provide a description of the topic, an analysis of the impact of the Internet on it, a summary of the existing studies and some directions for further research. This section is structured as follows: we first focus on each one of the processes identified by the Global Supply Chain Forum, we, then, continue with the enablers and, finally, we cover the impact of the Internet on the industry structure and competitive challenges, and on the firms' performance.

\subsection{The customer relationship management process}

The customer relationship management (CRM) process provides the structure for how the relationship with the customer is developed and maintained (Croxton, García-Dastugue et al. 2001). This process includes identifying key customers, segmenting them and tailoring products and services to their needs. The process also includes all activities related to working with customers in order to (1) improve processes, (2) eliminate demand variability and non-value added activities, and (3) develop agreements of metrics.

What is the impact of the Internet on this supply chain process? We can distinguish two different types of impacts: Internal and downstream. Internal effects refer to the impact of the Internet on the focal company. For example, through the Internet, all business units can have access to the same information about each customer. This means that all business units will be able to negotiate and relate with customers taking into account the same information.

The downstream effects refer to the impact of the Internet on the relationships with customers. One of the most important aspects of the downstream effects is that web sites allow companies to collect data as users navigate around them. This means that the Internet can generate a large amount of data, which can be very useful to CRM if it is analysed properly with Operations Research (OR) models ((Geoffrion and Krishnan 2001), (Sodhi 2001)). This has motivated the development of OR-based tools for predicting individual consumers' purchasing behaviours, leading to improvements in forecasting and inventory deployment (Sodhi 2001). Another downstream effect of the Internet is that it allows companies to provide new services to customers, increasing the companies' products and services offerings.

Table IV shows the classification of the papers related with the CRM process. (Boyer, Hallowell et al. 2002) and (Småros, Holmström et al. 2000) cover the downstream effect related to increasing the products and services offerings. (Scullin, Fjermestad et al. 2004) review the downstream effect of the impact of the Internet on the relationships with customers and the internal effect of how to manage the customer information within the company. Finally, (Tsikriktsis, Lanzolla et al. 2004) review the antecedents of the adoption of e-CRM. The papers of (Geoffrion and Krishnan 2001) and (Sodhi 2001), which cover the aspect related to the analysis of the data gathered through the Internet, have not been classified here because they describe some OR tools for planning and optimising different processes (and not only the CRM process). 
Table IV. Summary of references under detailed classification of the literature on the impact of the Internet on the CRM process

\begin{tabular}{|l|l|}
\hline \multicolumn{1}{|c|}{ Subclassification } & \multicolumn{1}{c|}{ References } \\
\hline $\begin{array}{l}\text { Increase of service and product } \\
\text { offerings }\end{array}$ & $\begin{array}{l}\text { (Småros, Holmström et al. 2000), (Boyer, Hallowell } \\
\text { et al. 2002) }\end{array}$ \\
\hline $\begin{array}{l}\text { Relation with the customer and how } \\
\text { to manage customer information }\end{array}$ & (Scullin, Fjermestad et al. 2004) \\
\hline $\begin{array}{l}\text { Antecedents of the adoption of e- } \\
\text { CRM }\end{array}$ & (Tsikriktsis, Lanzolla et al. 2004) \\
\hline
\end{tabular}

Further research regarding this process should try to analyse how different business units can use the same customer data. Future research should also try to determine what specific type of integration alternatives are available for organisations working with rapidly changing CRM and SCM support technologies. Future studies should also develop decision and OR tools to analyse the large amount of data gathered through the Internet. And, finally, researchers should also provide more empirical studies showing how the Internet is used to provide different product and service offerings (as it can be appreciated in Table IA in the appendix only one of the existing papers related this topic is empirically based).

\subsection{The customer service management process}

The customer service management process provides the firm's face to the customer (Croxton, García-Dastugue et al. 2001). It should be the single source of information to the customer. Real-time information is provided to the customer through interfaces with the firm's functions, such as operations and logistics (Croxton, García-Dastugue et al. 2001). This process includes strategic aspects, such as the development of the response procedures and the establishment of the infrastructure needed to respond. The process also includes tactical aspects, such as the recognition of the events that require a response, the implementation of the responses and the control of the process.

The most important impacts of the Internet on this process are in the internal and downstream parts of the supply chain. In the downstream part of the supply chain, the Internet can be used (1) to recognize events and listen to the customer, and (2) to communicate the response procedure to the customer. In the internal part of the process, the Internet can be used to enable information sharing on real time among different business units and among different functional areas of a firm. This internal information sharing will improve the response of the company to any event.

Table V illustrates the classification of papers related with this process. (Ellinger, Lynch et al. 2003) and (Rae-Smith and Ellinger 2002) cover the downstream part of the process, showing some examples of how companies communicate with their customers through the Internet. (Papathanassiou, Kardaras et al. 2003) covers not only the downstream part of the customer service management process but also the internal one. All three papers are empirically based and cover the information sharing impact of the Internet. Further research should follow the perspective of (Papathanassiou, Kardaras et al. 2003) in order to analyse intra-organisational and inter-organisational effects simultaneously. Cases showing 
how different business units share information on real time to provide a better customer service will be very valuable.

Table V. Summary of references under detailed classification of the literature on the impact of the Internet on the customer service management process

\begin{tabular}{|l|l|}
\hline \multicolumn{1}{|c|}{ Subclassification } & \multicolumn{1}{c|}{ References } \\
\hline Communicating with customers & $\begin{array}{l}\text { (Rae-Smith and Ellinger 2002), (Ellinger, Lynch et } \\
\text { al. 2003) }\end{array}$ \\
\hline $\begin{array}{l}\text { Communicating with customers \& } \\
\text { information sharing among different } \\
\text { functional units }\end{array}$ & (Papathanassiou, Kardaras et al. 2003) \\
\hline
\end{tabular}

\subsection{The demand management process}

The demand management process needs to balance the customers' requirements with the firm's supply capabilities (Croxton, García-Dastugue et al. 2001). This includes forecasting demand and synchronising it with distribution, production and procurement.

The Internet impacts this process along all the supply chain. Information sharing about actual sales enables companies to improve their forecasts. This affects the internal part of the supply chain (the focal company), but it also affects its upstream and downstream links. For example, in the grocery industry a manufacturer can receive information about the actual sales of its products at the stores. Internally, this information sharing can improve its forecasts, leading to an improvement in production planning and a reduction in stock levels. Downstream, this information sharing enables the customer (the grocery company) to eliminate the replenishment orders, because replenishment decisions can be made by the manufacturer. This means that the grocery customer reduces its order process costs and the stock levels (because its supplier's forecasts are better and stock-outs have decreased). Upstream, the information obtained about actual sales can be also shared with the focal company's suppliers. This improves the suppliers' forecasts, leading to an improvement in their production planning and a reduction in stocks.

The Internet affects this process along the supply chain, not only on the information sharing aspect, but also on the knowledge sharing aspect. The Internet not only enables the supply chain partners to access and share information, but also to access data analysis and modelling to jointly make a better planning and decision making. Decision technologies that offer the access to this knowledge, or the tools to obtain it, will become an important issue in the future ((Swaminathan and Tayur 2003), (Sodhi 2001)). One example of this knowledge sharing is Collaborative Planning Forecasting and Replenishment (CPFR). In these programs, customer, focal company and supplier do not only share information, they also plan together. In a CPFR program a forecasting support system is hold on an Internet server. This support system is updated with data from actual sales and other information provided by the grocery company and the manufacturer and provides the forecasts to the grocery retailer, the manufacturer and its suppliers. In September 1999, Henkel and Eroski (a Spanish grocery retailer) initiated a CPFR program. It resulted in an important improvement in the forecasts of both companies. Before implementing the program, half of the forecasts had a forecasting error higher than $50 \%$. Nine weeks after the implementation of the program, $75 \%$ of the sales forecasts had an error lower than 20\% (Jouenne 2000). 
We only found one paper analysing the impact of the Internet on this process. (McGuffog and Wadsley 1999) cover the information and knowledge share aspects of the Internet and consider the effects of e-commerce and collaborative planning on the supply chain. Further research should consider empirical analysis to determine the level of implementation of collaborative planning (such as CPFR) and collaborative replenishment (such as CRP) systems in different industries and the effects of this knowledge sharing on the performance of the supply chain. Collaborative planning includes the forecasting aspect of the demand management process, while collaborative replenishment covers the synchronisation part of this supply chain process. Research on decision models that can help managers to make collaborative planning along the supply chain is also needed. We think that multi-decision models which consider the objectives of different companies will play an important role in these decision and planning systems.

\subsection{The e-fulfilment process}

Order fulfilment is related with the effective management of all the activities needed to deliver the order to the customer. At the strategic level, there exists the need to design an efficient supply chain to enable a timely and accurate order fulfilment. At the operational level, the order fulfilment process consists on defining the following activities: generating, communicating, entering, processing, picking and delivering customer orders (Croxton, García-Dastugue et al. 2001). In a way, this process is about the integration of the manufacturing, logistics and marketing functions to ensure customer satisfaction and reduce total cost before, during and after the order fulfilment.

The impact of the Internet on the order fulfilment process has two main aspects. The first one is related to e-commerce and consists on fulfilling the customer orders placed through the Internet. While for customers the Internet has made the placement of orders more efficient, for the selling companies (of physical goods) the order fulfilment has become a critical operation (it is very costly and it is a key operation to obtain customer satisfaction). (Lee and Whang 2001) comment that to obtain an efficient order-fulfilment, new innovative strategies based on a good use of information and leveraging of existing resources must be applied.

The second aspect is related to the use of the Internet to improve the efficiency of the order fulfilment process for both online and offline businesses. The order fulfilment process requires the access and manipulation of a large amount of data, from customer orders to inventory levels. Therefore, the advantage of accessing and sharing data along the supply chain using Internet technologies can make this process more efficient and less costly. The possibility of all partners in a supply chain to see customer orders on real-time, or near real-time, can lead to a significant reduction of variability and costs and, at the same time, improve the responsiveness of the firm. However, firms can go a little further and use this data to generate knowledge by applying sophisticated analytical tools to anticipate changes and be better prepared to respond to customers' demand. At the operational level, these tools can go from statistical forecasting methods to analyse customer orders, to inventory systems to obtain the optimal inventory, and/or to vehicle routing systems to design the most efficient delivery routes. And, at the strategic level, these analytical tools can be used to design the most efficient supply network. 
In the literature review regarding the fulfilment process, one of the most covered impacts is how to deliver the goods sold through the e-commerce channel. This impact has been studied by the following authors: (Punakivi, Yrjölä et al. 2001), (Kämäräinen 2001), (Kotzab and Madlberger 2001), (Gurãu, Ranchhod et al. 2001), (Delfmann, Albers et al. 2002), (Marinus and De Koster 2002), (Boyd, Hobbs et al. 2003), (Da Silveira 2003), (Starr 2003), (Rabinovich 2004), (Rabinovich and Bailey 2004), (Boyer and Hult 2005), (Dadzie, Chelariu et al. 2005), (Rabinovich 2005) and (Thirumalai and Sinha 2005).

The impact of information sharing (through the Internet) on this process has been covered by six papers: (Crowley 1998), (Lee 2002), (Kelleher, El-Rahalibi et al. 2003), (Tyan, Wang et al. 2003), (Rabinovich and Evers 2003) and (Vannieuwenhuyse, Gelders et al. 2003). (Lee 2002) describes how information sharing can lead to a more efficient supply chain. (Crowley 1998), (Kelleher, El-Rahalibi et al. 2003) and (Vannieuwenhuyse, Gelders et al. 2003) focus on the impact of information sharing on transportation decisions such as routing and mode selection. (Rabinovich and Evers 2003) study the effects of information exchange on fulfilment activities, in particular on inventory decisions. And finally, (Tyan, Wang et al. 2003) analyse freight consolidation policies under an e-business model.

Finally, some authors analyse how to design an efficient supply chain and the most appropriate distribution strategy in an Internet context. (Dewman, Freimer et al. 2000) discuss distribution strategies in the information goods industry, while (Yrjölä 2001) focuses on the food and grocery industries. (Tsay and Agrawal 2004), (Kevin Chiang and Monahan 2005) and (Alptekinoglu and Tang 2005) analyse the impact of different distribution strategies for traditional and online retail stores. (Nagurney, Cruz et al. 2005) develop a supply chain equilibrium model for a supply chain consisting of manufacturers, distributors and retailers with electronic commerce. And, finally, (Piramuthu 2005) presents a framework for an automated supply chain configuration that takes advantages of the fast communication over the Internet.

Table VI. Summary of references under detailed classification of the literature on the impact of the Internet on the e-fulfilment process

\begin{tabular}{|l|l|}
\hline \multicolumn{1}{|c|}{ Subclassification } & \multicolumn{1}{c|}{ References } \\
\hline $\begin{array}{l}\text { e-commerce impact on order } \\
\text { fulfilment }\end{array}$ & $\begin{array}{l}\text { (Kämäräinen 2001), (Gurãu, Ranchhod et al. 2001), } \\
\text { (Kotzab and Madlberger 2001), (Punakivi, Yrjölä et } \\
\text { al. 2001), (Marinus and De Koster 2002), (Delfmann, } \\
\text { Albers et al. 2002), (Boyd, Hobbs et al. 2003), (Da } \\
\text { Silveira 2003), (Starr 2003), (Rabinovich 2004), } \\
\text { (Rabinovich and Bailey 2004), (Boyer and Hult } \\
\text { 2005), (Dadzie, Chelariu et al. 2005), (Thirumalai } \\
\text { and Sinha 2005), (Rabinovich 2005) }\end{array}$ \\
\hline $\begin{array}{l}\text { Improve the efficiency of order } \\
\text { fulfilment (online and offline) due to } \\
\text { information sharing }\end{array}$ & $\begin{array}{l}\text { (Crowley 1998), (Lee 2002), (Kelleher, El-Rahalibi } \\
\text { et al. 2003), (Vannieuwenhuyse, Gelders et al. 2003), } \\
\text { (Tyan, Wang et al. 2003), (Rabinovich and Evers } \\
\text { 2003) }\end{array}$ \\
\hline $\begin{array}{l}\text { Supply chain design and distribution } \\
\text { strategies }\end{array}$ & $\begin{array}{l}\text { (Dewman, Freimer et al. 2000), (Yrjölä 2001), (Tsay } \\
\text { and Agrawal 2004), (Piramuthu 2005), (Kevin } \\
\text { Chiang and Monahan 2005), (Nagurney, Cruz et al. } \\
\text { 2005), (Alptekinoglu and Tang 2005) }\end{array}$ \\
\hline
\end{tabular}


The directions for further research can enter into one of the following categories: (1) better use of information and the creation of knowledge by using actual and new analytical and decision tools; (2) new strategies applied to the e-fulfilment activities; and (3) more empirical research work, including case studies and business models about the implementation of e-fulfilment.

With respect to the first line of further research, the access to more data and information will put more emphasis in global optimisation along the entire supply chain, instead of the usual models that focus on local optimisation. More work considering the global supply chain is expected in this area. Also, more models using multi-criteria decision making that reflect the integration and collaboration aspects of the e-fulfilment process should be the subject of future work.

Regarding the study of new strategies for the e-fulfilment activities, one problem that seems to need more research is the so-called last mile. New delivery solutions or strategies that can combine profitability and service are still needed. The use of knowledge management, operations research and simulation techniques will be a must in the solution of this important problem of the e-commerce for physical goods. Further research should also focus on empirical studies, as very few papers on this process are field-based.

\subsection{The manufacturing flow management process}

The manufacturing flow management process deals with making the products and establishing the manufacturing flexibility needed to serve the target markets (Croxton, García-Dastugue et al. 2001). The process includes all activities necessary for: (1) managing the product flow through the manufacturing facilities, and (2) obtaining, implementing and managing flexibility (Croxton, García-Dastugue et al. 2001).

The Internet can have a positive impact on both aspects of the manufacturing flow management process. On one hand, the Internet provides the opportunity for demand and supply capacity data to be visible to all companies within a manufacturing supply chain, and therefore, the product flow through the manufacturing facilities can be improved. This visibility allows companies to be in a position to anticipate demand fluctuations and respond accordingly. The main effect of that is to reduce stocks and compress lead times. On the other hand, the Internet allows companies to be more flexible to respond to changes in demand. The Internet reduces the production cycles due to an increase in the speed of communication. "Companies like IBM, General Motors, General Electric and Boeing are assembling products for which the components are manufactured in many locations ... Using electronic bidding, assemblers get sub-assemblies up to 80 percent faster" (Gudmundsson and Walczuck 1999).

The Internet impacts on the manufacturing flow management process along all the supply chain. On one hand, the Internet can have an impact on how a company manages the internal part of this process. For example, a company can implement an Internet-based production planning system to analyse the production requirements and plans of the different manufacturing facilities the company has. This system would improve the decision-making process of the production planners and sales personnel and would reduce planning inaccuracies. (Xiong, Tor et al. 2003) and (Abid, D'amours et al. 2004) developed 
decision models to improve customer satisfaction by sharing knowledge in the manufacturing flow management. They proposed different collaborative planning systems which could be used jointly with other functional areas, such as sales and marketing. (Ko, Kim et al. 2001) proposed a system in which the central planning was developed in collaboration with external manufacturing partners with surplus capacity.

On the other hand, the Internet can have an impact on how the operations of the whole supply chain are managed. (Kehoe and Boughton 2001a) and (Kehoe and Boughton 2001b) suggest that the supply chain will change from an order-driven-lot-sizing approach to one more akin to a capacity-availability-booking approach supported by appropriate Internet search engines. And, (Bruun and Mefford 2004) analysed the impact of the Internet on lean production systems.

Table VII. Summary of references under detailed classification of the literature on the impact of the Internet on the manufacturing flow management process

\begin{tabular}{|l|l|}
\hline \multicolumn{1}{|c|}{ Subclassification } & \multicolumn{1}{c|}{ References } \\
\hline Improvements on the internal process & $\begin{array}{l}\text { (Ko, Kim et al. 2001), (Xiong, Tor et al. 2003), } \\
\text { (Abid, D'amours et al. 2004) }\end{array}$ \\
\hline $\begin{array}{l}\text { Management of the product flow } \\
\text { along the supply chain }\end{array}$ & $\begin{array}{l}\text { (Kehoe and Boughton 2001a), (Kehoe and Boughton } \\
\text { 2001b), (Bruun and Mefford 2004) }\end{array}$ \\
\hline
\end{tabular}

Regarding the manufacturing planning and control systems, the academic challenges are to develop alternative business models, as well as to determine the tools and techniques by which the benefits from such models can be demonstrated to practitioners (Kehoe and Boughton 2001a). Further research should also be more empirically based. Finally, researchers should develop more decision models that take into account the global aspects of the supply chain to help improving the manufacturing planning.

\subsection{The e-procurement process}

The procurement process relates a firm with its suppliers and it is a fundamental process in SCM. At the strategic level, the firm must define the corporate, manufacturing and sourcing strategies and identify the products and services that should be acquired from outside (Croxton, García-Dastugue et al. 2001). And, at the operational level, all the procurement activities, such as reviewing suppliers, identifying opportunities, and developing and implementing product or service agreements, should be developed and controlled (Croxton, García-Dastugue et al. 2001).

The e-procurement process supports the procurement and sourcing activities via Internet technologies and enables an efficient negotiation between buyers and suppliers. We distinguish two types of e-procurement: marketplaces and B2B. Marketplaces bring multiple buyers and sellers together in a virtual market, meanwhile B2B e-procurement is a one to one relationship.

Since the procurement or supplier relationship process consists on a relationship between businesses and needs a large amount of information sharing and transfer, the use of the Internet has had a big impact on this process. Several firms have implemented eprocurement solutions not only to reduce costs, but also to make more efficient this key 
process. The major impact of the Internet on the procurement process is certainly on information sharing, since this process involves retrieving, sharing and storing a large amount of data and information. However, knowledge sharing is becoming also a key issue in this process. Firms can apply analytical models to previous data and obtain important information to make better decisions (Swaminathan and Tayur 2003).

We have subclassified the papers on this topic on 5 categories: general aspects of the use of the Internet on the procurement process, marketplaces, e-auctions, B2B procurement, and decision models for procurement decisions in an Internet environment. The general aspects of how firms use the Internet to streamline the process and which are the factors leading to a higher willingness to adopt Internet procurement have been covered by the following papers: (Brenner and Hamm 1996), (Min and Galle 1999), (de Boer, Harink et al. 2002), (Boyer and Olson 2002), (Kaufmann and Carter 2002), (Olson and Boyer 2003), (Bartezzaghi and Ronchi 2004), (Ordanini 2005) and (Saeed, Malhotra et al. 2005). (Croom 2000) also conducts an empirical study on the use of the Internet on the procurement process but he focuses on maintenance, repair, and operating (MRO) supplies.

The role and benefits of marketplaces have been covered extensively. Marketplaces have been described by (Gudmundsson and Walczuck 1999), (Emiliani 2000), (Kaplan and Sawhney 2000), (Mahadevan 2000), (Wise and Morrison 2000), (Barratt and Rosdahl 2002), (Emiliani and Stec 2002a) and (Emiliani and Stec 2002b); and empirically analysed by (Hohner, Rich et al. 2003), (Mahadevan 2003), (Bartezzaghi and Ronchi 2004) and (Smart 2005). (Essig and Arnold 2001) analysed the possibilities of marketplaces for buyers and developed an analytical framework. Finally, other authors, such as (Grieger 2003) and (Kleindorfer and $\mathrm{Wu} 2003$ ) conducted a literature review on the topic of marketplaces.

The topic of auctions using the Internet has been covered by several authors. See for example: (Bapna, Goes et al. 2003), (Carr 2003), (Pinker, Seidmann et al. 2003), (Snir and Hitt 2003), (Emiliani and Stec 2004), (Parente, Venkataraman et al. 2004), (Talluri and Ragazt 2004), (Teich, Wallenius et al. 2004), (Easley and Tenorio 2004), (Carare and Rothkopf 2005), (Deltas and Engelbrecht-Wiggans 2005), (Ding, Eliashberg et al. 2005) and (Gunluk, Ladányi et al. 2005).

B2B e-procurement has been covered by some authors, however, it has not been so studied as the marketplace topic. (Deeter-Schmelz, Bizzari et al. 2001) evaluate the impact of supplier support on buyers' adoption of the Internet for corporate-related purchasing activities while (Calosso, Cantamessa et al. 2003) present an Internet platform for B2B procurement. (Knudsen 2003) and (Sparks and Wagner 2003) cover this topic from a descriptive point of view presenting main concepts and frameworks applied to different B2B procurement processes.

Finally, the application of decision models to e-procurement strategies and marketplaces has also a relevant presence in the literature. Authors like (Lee and Whang 2002), (Peleg, Lee et al. 2002), (Wang and Benaroch 2004), (Scott and Scott 2004), (Seifert, Thonemann et al. 2004), (Hazra, Mahadevan et al. 2004), (Granot and Sošic 2005), (Metty, Harlan et al. 2005) and (Wu and Kleindorfer 2005) developed decision models to help managers make decisions regarding procurement and pricing strategies, operating cost reductions of marketplaces, and the structure of the optimal portfolio of transactions. 
(Roberts and Mackay 1998) discuss how e-commerce may be used to support a portfolio of supplier relationships and use the case of BT Supply Management who has developed a supplier relationship framework to categorise suppliers and select the most appropriate eprocurement strategy. As the focus of this paper is more on matching supply chain relationship with the type of e-procurement tool, we have classified this paper under the supply chain relationship topic.

Table VIII. Summary of references under detailed classification of the literature on the impact of the Internet on the e-procurement process

\begin{tabular}{|l|l|}
\hline \multicolumn{1}{|c|}{ Subclassification } & \multicolumn{1}{c|}{ References } \\
\hline $\begin{array}{l}\text { General aspects of the use of the } \\
\text { Internet on the procurement process }\end{array}$ & $\begin{array}{l}\text { (Brenner and Hamm 1996), (Min and Galle 1999), } \\
\text { (Croom 2000), (de Boer, Harink et al. 2002), (Boyer } \\
\text { and Olson 2002), (Kaufmann and Carter 2002), } \\
\text { (Olson and Boyer 2003), (Bartezzaghi and Ronchi } \\
\text { 2004), (Ordanini 2005), (Saeed, Malhotra et al. 2005) }\end{array}$ \\
\hline Marketplaces & $\begin{array}{l}\text { (Gudmundsson and Walczuck 1999), (Kaplan and } \\
\text { Sawhney 2000), (Mahadevan 2000), (Wise and } \\
\text { Morrison 2000), (Emiliani 2000), (Essig and Arnold } \\
\text { 2001), (Barratt and Rosdahl 2002),(Emiliani and Stec } \\
\text { 2002a), (Emiliani and Stec 2002b), (Hohner, Rich et } \\
\text { al. 2003), (Mahadevan 2003), (Grieger 2003), } \\
\text { (Kleindorfer and Wu 2003), (Bartezzaghi and Ronchi } \\
\text { 2004), (Smart 2005) }\end{array}$ \\
\hline e-auctions & $\begin{array}{l}\text { (Bapna, Goes et al. 2003), (Carr 2003), (Pinker, } \\
\text { Seidmann et al. 2003), (Snir and Hitt 2003), (Easley } \\
\text { and Tenorio 2004), (Emiliani and Stec 2004), } \\
\text { (Parente, Venkataraman et al. 2004), (Talluri and } \\
\text { Ragazt 2004), (Teich, Wallenius et al. 2004), (Carare } \\
\text { and Rothkopf 2005), (Deltas and Engelbrecht- } \\
\text { Wiggans 2005), (Ding, Eliashberg et al. 2005), } \\
\text { (Gunluk, Ladányi et al. 2005) }\end{array}$ \\
\hline Decision models for procurement & $\begin{array}{l}\text { (Tucker and Jones 2000), (Deeter-Schmelz, Bizzari et } \\
\text { al. 2001), (Calosso, Cantamessa et al. 2003), } \\
\text { (Knudsen 2003), (Sparks and Wagner 2003) }\end{array}$ \\
\hline B2B e-procurement & $\begin{array}{l}\text { (Lee and Whang 2002), (Peleg, Lee et al. 2002), } \\
\text { (Seifert, Thonemann et al. 2004), (Wang and } \\
\text { Benaroch 2004), (Scott and Scott 2004), (Hazra, } \\
\text { Mahadevan et al. 2004), (Metty, Harlan et al. 2005), } \\
\text { (Granot and Sošic 2005), (Wu and Kleindorfer 2005) }\end{array}$ \\
\hline
\end{tabular}

The e-procurement process is one of the most studied within the e-SCM literature. The topics most covered are marketplaces, auctions and the development of decision models for procurement decisions in an Internet environment. The benefits of using the Internet on the procurement processes have also been well analysed through empirical studies. However, we have identified some research gaps: More studies regarding the benefits and implementation barriers of using B2B procurement should be conducted. Further research should also compare the benefits of B2B with respect to the EDI technology. Also, more studies (like the one of (Roberts and Mackay 1998)) should analyse how to strategically segment e-procurement strategies (for example, for which products/relationships are more 
suitable B2B applications and for which products/relationships are more appropriate marketplaces).

\subsection{The product development and commercialisation process}

The product development and commercialisation process is critical to the success of the firm. It is the set of activities that companies should undertake to successfully develop and launch products. According to (Croxton, García-Dastugue et al. 2001), this process includes the following subprocesses or activities: defining new products, establishing the cross-functional product development team, designing and building prototypes, determining the distribution channel for the new product, and measuring the process performance. The process includes integrating customers and suppliers into the product development in order to launch the right product and to reduce the time to market. For example, Microsoft used a web collaboration tool to bring the Xbox video game console to market two months ahead of schedule (Keenan and Ante 2002).

What is the impact of the Internet on this process? One of the most important impacts is to enable collaboration among different functional areas and companies. Internet-based product development can make product design a truly collaborative process among designers, manufacturers, suppliers and customers without the limitations of geographical location and time zone (Cheng, Pan et al. 2000). Taking the perspective of a focal company, we can distinguish three types of effects: internal, downstream and upstream effects. Internal effects refer to the impact of the Internet on the focal company. The Internet enables the collaboration of different functional units in the new product development process. Downstream effects refer to the impact of the Internet on the relationships with customers: the Internet facilitates the involvement of customers and/or end-users in the design of new products, increasing the response of the company to the customer wants and needs. The company can also use the Internet to study the market in a faster and cheaper way. And, the upstream effects refer to the impact of the Internet on the relationships with suppliers: Suppliers can be involved in the process as early as possible in order to reduce costs and compress the time to market.

In the literature review on this topic, we found that the internal aspects were covered by (Xie and Salvendy 2003) and (Xie, Xu et al. 2005), while the upstream impacts were analysed by (Elliman and Orange 2000) and the downstream ones by (Finch 1999), (Cheng, Pan et al. 2000) and (Xie, Tu et al. 2001). Finally, (Xie, Tu et al. 2003) presented a literature of the existing one-of-a-kind products systems and analysed the recent approaches of Internet-based design and manufacturing systems. They focused on Internet based-collaborative design along the supply chain, covering the internal, upstream and downstream effects.

The existing studies have covered the areas of information and knowledge sharing, and the upstream, internal and downstream perspectives. However, only one study, out of the seven found, is empirically based. Further research should put more emphasis on conducting empirical studies in order to determine the real use and advantages of using the Internet in the product development and commercialisation process. 
Table IX. Summary of references under detailed classification of the literature on the impact of the Internet on the product development and commercialisation process

\begin{tabular}{|l|l|}
\hline \multicolumn{1}{|c|}{ Subclassification } & \multicolumn{1}{c|}{ References } \\
\hline Internal collaboration & (Xie and Salvendy 2003), (Xie, Xu et al. 2005) \\
\hline Upward collaboration & (Elliman and Orange 2000) \\
\hline Downward collaboration & $\begin{array}{l}\text { (Finch 1999), (Cheng, Pan et al. 2000), (Xie, Tu et al. } \\
\text { 2001) }\end{array}$ \\
\hline Collaboration along the supply chain & (Xie, Tu et al. 2003) \\
\hline
\end{tabular}

\subsection{The reverse logistics and returns process}

Effective returns management is a key process in today's business. The returns policy is one of the most attractive tools to stay competitive (Rogers and Tibben-Lemke 1999). This process includes all the elements in a supply chain and involves decisions on return avoidance practices, gate keeping, disposition guidelines, development of a returns network and flow options (Croxton, García-Dastugue et al. 2001).

How can the Internet help this process? Managing returns involves managing different types of data: reasons for return (defective, in warranty, old, etc.), conditions of the product, point of return, instructions to customers, etc. The major impact of the Internet on this process consists on providing better information and knowledge to all members of the supply chain involved in this process.

Another impact of the Internet on the returns process is related with e-commerce. Ecommerce generates more returns than the traditional commerce (Gentry 1999) and (Meyer 1999)). Handling these returns efficiently is, without any question, an important issue for companies selling through the Internet. Not only because the volume of returns is higher in the e-commerce than in the traditional channel, but also because the logistics involved is different. For example, in the traditional commerce, a customer that wants to return a product (within a few days of having bought it) he just has to go back to the store and return it. On the Internet channel this is different: How should the product be returned? Who should pay for this return? And, what should be the best supply chain structure to recover these products efficiently? It is not clear that the same structures of the direct supply chain should be used. Designing efficient close-loop supply chains is a key element to improve the reverse logistics and returns process, and the Internet can play an important role on this aspect.

In the literature review regarding this process, the existing papers cover both types of impact: sharing information through the Internet and returns of e-commerce sales. In Table X we present a classification of the papers in this topic. (Spengler and Schröter 2003) provide a case study to show how an Internet tool can be used to provide information to all members of the supply chain involved in the returns process. (van Nunen and Zuidwijk 2004) describe the impact of information and communication technology, including the Internet, on the three perspectives of a Close-Loop Supply Chains: processes, products and customers. (Vlachos and Dekker 2003) provide a mathematical model to better manage the returns for Internet sales, and (Mukhopadhyay and Setoputro 2004) 
analyse, for e-retailing businesses, the trade off between the increased revenue due a generous returns policy and the increased cost due the increased quantity of products return.

Table X. Summary of references under detailed classification of the literature on the impact of the Internet on the reverse logistics and returns process

\begin{tabular}{|l|l|}
\hline \multicolumn{1}{|c|}{ Subclassification } & \multicolumn{1}{c|}{ References } \\
\hline Information on returns & $\begin{array}{l}\text { (Spengler and Schröter 2003), (van Nunen and } \\
\text { Zuidwijk 2004) }\end{array}$ \\
\hline Returns of e-commerce sales & $\begin{array}{l}\text { (Vlachos and Dekker 2003), (Mukhopadhyay and } \\
\text { Setoputro 2004) }\end{array}$ \\
\hline
\end{tabular}

In the next future, we expect the development of decision models to solve the problems related to the huge amount of returns associated with e-commerce. Some lines of further research are: the dynamic estimation of expected demand of serviceable returns (Vlachos and Dekker 2003), inventory models considering returns, production planning including recoverable parts and assemblies (Soto and Lourenço 2002), routing and distribution systems to handle returns, etc. Also, the possibility of sharing, through the web, information related to the returns puts more emphasis on developing analytical tools to help decision makers. More studies like the one provided by (Spengler and Schröter 2003) are expected. Finally, researchers should also focus on the design of closed-loop supply chains that make use of the Internet to manage efficiently the recovery of the return products, as the work of (van Nunen and Zuidwijk 2004) does.

\subsection{Impact of the Internet on several supply chain processes}

Under this heading we have classified all the papers which aim is to analyse the impact of the Internet on several supply chain processes. Table XI shows the papers classified under this category.

Seven papers have been classified into this category. (Gunasekaran, H.B. Marri et al. 2002) and (Sarkis, Meade et al. 2004) are conceptual papers. (Gunasekaran, H.B. Marri et al. 2002) define e-commerce and examine its application in manufacturing, retailing and service operations. (Sarkis, Meade et al. 2004) focuses on a discussion of forward and reverse e-logistics and their relationship to the natural environment.

(Cagliano, Caniato et al. 2003), (Muffatto and Payaro 2004) and (Croom 2005) are empirically based papers. (Cagliano, Caniato et al. 2003) explore the actual adoption of Internet technologies in several supply chain processes by a large sample of European manufacturing firms. And in (Cagliano, Caniato et al. 2005) they provide an update of the previous paper. (Muffatto and Payaro 2004) analyse the benefits achieved in the procurement and fulfilment processes as a result of the Internet usage in these processes. (Croom 2005) through an interview study with a large sample of organisations analyses the impact of e-business on supply chain strategy, examining three representative areas of SCM: the procurement, CRM and fulfilment processes.

The paper of (Robinson, Sahin et al. 2005) is a simulation-based paper which aim is to investigate the impact of electronic replenishment (the seamless automation of the buyer's 
procurement and vendor's fulfilment processes) on the operational activities and performance of a make-to-order supply chain.

(Johnson and Whang 2002) and (Gunasekaran and Ngai 2004) conduct a literature review. (Johnson and Whang 2002) examine how the web is changing SCM and classify the papers into three main categories: e-commerce, e-procurement and e-collaboration. (Gunasekaran and Ngai 2004) conduct a literature review focusing on the role and implications of IT in SCM. They classified the papers according to what they called the major components of IT-enabled SCM: strategic planning for IT in SCM, virtual enterprise and SCM, ecommerce and SCM, infrastructure for IT in SCM, Knowledge and IT management in SCM, and implementation of IT in SCM.

Our paper follows the same methodology as (Johnson and Whang 2002) and (Gunasekaran and Ngai 2004), but it differs from them in the classification scheme and the framework used to classify the papers. We have classified the papers using a framework based on the idea that SCM is the management of supply chain processes. As (Croom 2005) pointed out very recently, there is some debate about the scope of SCM and one way of dealing with the diversity of SCM definitions is to concentrate on the core processes and functions relating to the management of supply chains (for example, fulfilment, operations planning and procurement).

Table XI. Summary of references of the literature on the impact of the Internet on several supply chain processes

\begin{tabular}{|l|}
\hline References \\
\hline (Gunasekaran, H.B. Marri et al. 2002), (Johnson and Whang 2002), (Cagliano, Caniato et al. \\
2003), (Gunasekaran and Ngai 2004), (Muffatto and Payaro 2004), (Sarkis, Meade et al. \\
2004), (Cagliano, Caniato et al. 2005), (Croom 2005), (Robinson, Sahin et al. 2005) \\
\hline
\end{tabular}

We defined e-SCM as the impact of the Internet on the integration of key business processes. Future studies should investigate the adoption of Internet enabling tools to facilitate integration along the supply chain. Some aspects to be studied are: in which processes is the Internet most used to integrate with other functional areas and/or supply chain members? In case of differences between processes, which are the reasons of these differences in the level of implementation of Internet enabling tools? Which are the benefits that companies are achieving with the implementation of the Internet in different supply chain processes? We expect more research on this area. In fact, the papers analysing the impact of the Internet on several supply chain processes have been published very recently.

\subsection{Supply chain relationships}

SMC is "the management of upstream and downstream relationships with suppliers and customers to deliver superior customer value at less cost to the supply chain as a whole" (Christopher 1998).

Companies strategically segment their relationships and establish arm's length relationships with some supply chain members and strategic partnerships and alliances 
with others. The Internet has an impact on how companies manage all type of relationships. For the strategic partnership approach, the Internet enables companies to share information and knowledge, leading to higher levels of coordination and collaboration. And, for the arm's length approach, firms can benefit from the use of dynamic pricing structures that are web-enabled.

The existing papers are mainly conceptual (see Table IA in the appendix). As it can be appreciated in Table XII, three different subgroups can be identified. There are some papers which focus on the collaboration nature of Internet-enabled supply chain relationships (see for example, (O'Keefe 2001a), (O'Keeffe 2001b) and (Williams, Esper et al. 2002) and (Yeh 2005)). Another group of papers focuses on the need of matching the ebusiness model with the type of relationship kept with the supply chain member: (Roberts and Mackay 1998), (Jap and Mohr 2002), (Caputo, Cucchiella et al. 2005) and (Nair 2005). And finally, there are some papers that focus on the impact of the Internet on the nature of the supply chain relationships and how to manage them: (Golicic, Davis et al. 2002), (Agarwal and Shankar 2003) and (White and Daniel 2004).

Table XII. Summary of references under detailed classification of the literature on the impact of the Internet on the supply chain relationships

\begin{tabular}{|l|l|}
\hline \multicolumn{1}{|c|}{ Subclassification } & \multicolumn{1}{c|}{ References } \\
\hline Collaboration & $\begin{array}{l}\text { (O'Keefe 2001a), (O'Keeffe 2001b), (Williams, Esper } \\
\text { et al. 2002), (Yeh 2005) }\end{array}$ \\
\hline $\begin{array}{l}\text { Match e-business model with type of } \\
\text { relationship }\end{array}$ & $\begin{array}{l}\text { (Roberts and Mackay 1998), (Jap and Mohr 2002), } \\
\text { (Caputo, Cucchiella et al. 2005), (Nair 2005) }\end{array}$ \\
\hline Impact on relationships & $\begin{array}{l}\text { (Golicic, Davis et al. 2002), (Agarwal and Shankar } \\
\text { 2003), (White and Daniel 2004) }\end{array}$ \\
\hline
\end{tabular}

Further research should try to conduct more empirically-based studies in order to analyse which has been the real impact of the Internet on the management of supply chain relationships. Some lines of future research are: (1) to examine in a greater depth (by extending the sample to a larger number of firms) the impact of e-commerce on relationships (Golicic, Davis et al. 2002); (2) to study it from a dyadic or a supply chain perspective ((Golicic, Davis et al. 2002) examined it from a single-firm point of view); and (3) to empirically test the relationship established by (Jap and Mohr 2002) between type of relationship (relational or transactional) and the Internet efficiency.

\subsection{Information flows}

Under this heading we have classified all papers describing how information flows in a supply chain enabled by Internet technologies. Although business-to-business electronic trading has been around for more than 20 years thanks to EDI, the complexity of early EDI packages, rival standards and its relatively high costs have traditionally excluded many companies, especially small firms (Kehoe and Boughton 2001b). The relatively easy access to the Internet (most organisations have a telephone and a PC) makes this technology have a bigger impact on information flows than EDI. 
The impact of the Internet on the information flows of a supply chain consists mainly on enabling companies to share information on real time. For years, ERP systems provided the ability to access information from various parts of the organisation. However, their potential could not be explored and expanded due to a lack of common standards and cost of access. The growth of e-business enabled to share information, made available from ERP systems, with other supply chain members (Swaminathan and Tayur 2003).

This sharing of information affects all supply chain processes and some of its effects are: inventory can be reduced due to better forecasts, inventory allocation in different retail outlets can be done more effectively, advanced planning and optimisation tools can be used because there is more information available, collaborative planning and design can be implemented, etc.

The papers in this topic can be subclassified in the following categories (see Table XIII): integrated information flow along the supply chain using Internet technologies, expand ERP to SCM software via the Internet, the Internet opens up new perspectives for SME, development of knowledge management systems, virtual integration, and e-business models (drivers, software selection, etc).

The following papers analyse the integrated information flow along the supply chain using Internet technologies. (Van Hoek 2001), (Disney, Naim et al. 2004), (Lyons, Coronado Mondragon et al. 2005), (Gaur, Giloni et al. 2005), (Agi, Ballot et al. 2005) describe the importance and impact of the integrated flow of information along the supply chain. (Wilson and Clarke 1998) and (James, Grosvenor et al. 2004) describe how the Internet can be used to collect, locate and disseminate traceability data. (Lewis and Talalayevsky 2004) investigate information-driven supply chain structures. And, finally, (Turowski 2002) and (Zhu 2004) evaluate the informational effects of B2B and e-commerce.

(Davenport and Brooks 2004), (Themistocleous, Irani et al. 2004), (Bendoly and Schoenherr 2005) and (Biehl 2005) analyse how to extend ERP systems into SCM systems. (De Burca, Fynes et al. 2005) examine how Small and Medium Enterprises (SME) are responding to the challenge of ERP systems and Internet technologies to enhance performance and improve competitiveness. As they focus SMEs we have classified this paper under both categories: expand ERP to SCM software via the Internet, and the Internet opens up new perspectives for SME.

(Stefansson 2002), (Chan and Chung 2002) and (Larson, Carr et al. 2005) discuss how the advent of the Internet opens up new perspectives for Small and Medium Enterprises (SME).

The development of knowledge management systems has been analysed by: (Greis and Kasarda 1997), (Tatsiopoulos, Ponis et al. 2002), (Yoo and Kim 2002) and (Mondal and Tiwari 2003). (Greis and Kasarda 1997) describe how information flows provide an opportunity for new logistical systems and knowledge-based tools. (Tatsiopoulos, Ponis et al. 2002), (Yoo and Kim 2002) and (Mondal and Tiwari 2003) provide the development of data and/or knowledge management systems for sharing information and/or knowledge throughout the supply chain.

(Upton and McAfee 1996), (Bal, Wilding et al. 1999), (Sarkis and Sundarraj 2002) have been classified under the virtual integration category. (Upton and McAfee 1996) and (Sarkis and Sundarraj 2002) cover the brokering situation of the virtual and e-commerce 
enabled organisations while (Bal, Wilding et al. 1999) describe how the Internet enables the creation of virtual teams.

Finally, there is a set of papers that analyse different topics related to e-business models. (Sarkis and Talluri 2004) analyse the decision of selecting the e-commerce technology and software most adequate for an integrated supply chain. (Hayes and Finnegan 2005) develop a framework for assessing the suitability of different e-business models. And, finally, (Power 2005) evaluates the relative importance of various drivers of informationtechnology-related performance in an e-business context.

Table XIII. Summary of references under detailed classification of the literature on information flows

\begin{tabular}{|l|l|}
\hline \multicolumn{1}{|c|}{ Subclassification } & \multicolumn{1}{c|}{ References } \\
\hline $\begin{array}{l}\text { Integrated information flow along the } \\
\text { supply chain using Internet } \\
\text { technologies }\end{array}$ & $\begin{array}{l}\text { (Wilson and Clarke 1998), (Van Hoek 2001), } \\
\text { (Turowski 2002), (Lewis and Talalayevsky 2004), } \\
\text { (Disney, Naim et al. 2004), (James, Grosvenor et al. } \\
\text { 2004), (Zhu 2004), (Lyons, Coronado Mondragon et } \\
\text { al. 2005), (Gaur, Giloni et al. 2005), (Agi, Ballot et } \\
\text { al. 2005) }\end{array}$ \\
\hline $\begin{array}{l}\text { Expand ERP to SCM software via } \\
\text { the Internet }\end{array}$ & $\begin{array}{l}\text { (Davenport and Brooks 2004), (Themistocleous, Irani } \\
\text { et al. 2004), (Biehl 2005), (De Burca, Fynes et al. } \\
\text { 2005), (Bendoly and Schoenherr 2005) }\end{array}$ \\
\hline $\begin{array}{l}\text { The Internet opens up new } \\
\text { perspectives for SME }\end{array}$ & $\begin{array}{l}\text { (Stefansson 2002), (Chan and Chung 2002), (De } \\
\text { Burca, Fynes et al. 2005), (Larson, Carr et al. 2005) }\end{array}$ \\
\hline $\begin{array}{l}\text { Development of knowledge } \\
\text { management systems }\end{array}$ & $\begin{array}{l}\text { (Greis and Kasarda 1997), (Tatsiopoulos, Ponis et al. } \\
\text { 2002), (Yoo and Kim 2002), (Mondal and Tiwari } \\
\text { 2003) }\end{array}$ \\
\hline Virtual integration & $\begin{array}{l}\text { (Upton and McAfee 1996), (Bal, Wilding et al. } \\
\text { 1999), (Sarkis and Sundarraj 2002) }\end{array}$ \\
\hline $\begin{array}{l}\text { e-business models (drivers, software } \\
\text { selection, etc) }\end{array}$ & $\begin{array}{l}\text { (Sarkis and Talluri 2004), (Hayes and Finnegan } \\
\text { 2005), (Power 2005) }\end{array}$ \\
\hline
\end{tabular}

Most of the existing papers describe the impact of the Internet on information flows or develop support systems to enable the sharing of information through the Internet. Very few papers are empirically-based, and the existing ones are case studies, which aim is to explore this impact on the real world. One line of further research should be to conduct surveys in order to generalize the findings of these case studies. Some research objectives should be: to determine the level of adoption of virtual teams and to analyse what type of information are companies really sharing through the Internet.

\subsection{Planning and optimisation}

Planning and optimisation are key elements in SCM. Firms can use these techniques to anticipate problems and issues and, therefore, better respond to the needs of the customer. The availability of information and communication technologies, together with the last developments in the fields related to planning and optimisation (Operations Research and Statistics), have led to improvements in performance and the achievement of competitive advantages. 
In this topic we have included the papers that describe and develop web-based planning and optimisation tools for SCM. (Geoffrion and Krishnan 2001), (Keskinocak and Tayur 2001), (Sodhi 2001) and (Swaminathan and Tayur 2003) describe the impact of planning and optimisation web-based techniques on supporting decisions and give insights for better SCM. (Cohen, Kelly et al. 2001), (Lee and Chen 2002) and (Shen, Kremer et al. 2003) describe web-based applications to support planning and optimisation. These web applications include decision technologies such as data management, statistical analysis, forecasting, data mining, optimisation models, exact and heuristic solution methods, simulation, economic models, game theory, etc. Nowadays many of these applications reside or are available through Application Service Providers (ASP). ASPs are firms who host specific applications to be used by other companies on a fee basis. These services will be critical for small players, who cannot afford the major investments in the infrastructure needed to participate in the collaborative supply chain.

The Internet has had and will have a great impact on the development of decision technology. Firstly, it helps to improve the planning and optimisation within the supply chain by providing access to decision support systems. And, secondly, the decision technology can take advantage of the ability to access an enormous quantity of data and information available through the Internet.

In this topic, most of the papers use decision models as the main methodology and cover the impacts of information and knowledge sharing. All these papers were written between 2001 and 2003. Afterwards, the papers we found related with optimisation and the Internet were about the hot topic of dynamic pricing, which we have not included in this paper. Table XIV shows the subclassification of papers related with this topic.

Table XIV. Summary of references under detailed classification of the literature on the impact of the Internet on the planning and optimisation

\begin{tabular}{|l|l|}
\hline \multicolumn{1}{|c|}{ Subclassification } & \multicolumn{1}{c|}{ References } \\
\hline $\begin{array}{l}\text { Description of the impact of web- } \\
\text { based planning and optimisation } \\
\text { techniques on SCM }\end{array}$ & $\begin{array}{l}\text { (Geoffrion and Krishnan 2001), (Keskinocak and } \\
\text { Tayur 2001), (Sodhi 2001), (Swaminathan and Tayur } \\
\text { 2003) }\end{array}$ \\
\hline $\begin{array}{l}\text { Web-based planning and } \\
\text { optimisation applications }\end{array}$ & $\begin{array}{l}\text { (Cohen, Kelly et al. 2001), (Lee and Chen 2002), } \\
\text { (Shen, Kremer et al. 2003) }\end{array}$ \\
\hline
\end{tabular}

E-SCM is posing new and challenging problems that need to be solved. Therefore, there exists interesting opportunities for decision technology, operations research models, optimisation and economic theory to provide insights about planning and optimisation in the e-supply chain. We expect more developments on real-time tools, modelling and decision systems that use real-time data available through the Internet. These will require solution techniques based on heuristics and approximation algorithms. Another important issue to be studied and developed is multi-criterion decision making, which can provide very interesting insights in the collaborative supply chain (due to the possible conflict of objectives when several firms interact in a supply chain and the models used to make decisions are based on incomplete information). We also expect more developments on Internet-based decision support systems and applications that use the Internet to provide solutions and insights to the problems posed by e-SCM. By developing new planning, 
decision and optimisation models and solution techniques, researchers will contribute to help managers to make better business decisions. Finally, we also expect more real applications of e-SCM decision problems and case studies on the implementation of decision technologies using the Internet.

\subsection{Industry structure and competitive challenges}

This topic comprises all the papers that analyse the impact of the Internet on the industry structure and how companies are responding to competitive challenges using the Internet. Table XV shows the papers classified under this topic.

(Clarke 1998) defines concepts for virtual logistics. (Graham and Hardaker 2000) describes the new competitive challenges being realised from the Internet. (Graham, Burnes et al. 2004) and (Lewis, Graham et al. 2005) examine how the Internet is transforming the industry structure and the supply chain for music while (Dedrick and Kraemer 2005) analyse the impact on the PC industry. (Mclvor and Humphreys 2004) present a framework that clarifies the role of an inter-organisational information system provider (intermediary). And, finally, (Richard and Devinney 2005) suggest that there are two generic B2B strategies: Modularisation (to rent internal capabilities to others in the industry) and architectural entrepreneurship (to alter how the supply chain is arranged by allowing a central coordinating firm to overcome problems associated with trust and information asymmetry).

Table XV. Summary of references of the literature on industry structure and competitive challenges

\begin{tabular}{|l|}
\hline \multicolumn{1}{|c|}{ References } \\
\hline (Clarke 1998), (Graham and Hardaker 2000), (Graham, Burnes et al. 2004), (Mclvor and \\
Humphreys 2004), (Dedrick and Kraemer 2005), (Lewis, Graham et al. 2005), (Richard and \\
Devinney 2005) \\
\hline
\end{tabular}

Most of the papers under this heading are conceptual, although some of them use existing case studies to analyse their framework. Only two industries have been analysed: the PC and the music. Further research should consider other industries. A cross-industry study would be very valuable. It would also be very interesting to investigate which characteristics of the product/service offered determine the impact of the Internet on the industry structure (value chain, distribution channel, etc.).

\subsection{Impact on performance}

Under this heading we have classified all the papers which aim is to analyse the impact of the Internet on performance (without analysing any specific supply chain process). Table XVI shows the papers classified under this category. As it can be appreciated in this table, seven papers analyse the impact of the Internet enabled supply chain on performance.

(Frohlich 2002) investigates the relationship between Internet-enabled supply chain integration strategies and performance in manufacturing and services. (Frohlich and Westbrook 2002) analyse the relationship between e-integration and performance and investigate the main barriers that impede integration. (Rubiano Ovalle and Crespo Marquez 
2003) analyse the impact on performance of three different levels of Internet-enabled collaboration. (Cassivi, Lefebvre et al. 2004) analyse the relative efficiency of different ecollaboration tools and their impact on the performance of individual firms positioned along the supply chain. (Iyer, Germain et al. 2004) investigate the relationship between ecommerce and time-delivery performance. (Auramo, Kauremaa et al. 2005) provide empirical evidence of the benefits from information technologies in SCM. And, finally, (Eng 2005) analyses the impact of Internet adoption on the relationship between crossfunctional integration and customer satisfaction/supply chain responsiveness.

All of them analyse the topic from an empirical point of view, using surveys and/or case studies, except for (Rubiano Ovalle and Crespo Marquez 2003) who use simulation.

Table XVI. Summary of references of the literature on the impact of the Internet on performance

\begin{tabular}{|l|}
\hline \multicolumn{1}{|c|}{ References } \\
\hline (Frohlich 2002), (Frohlich and Westbrook 2002), (Rubiano Ovalle and Crespo Marquez \\
2003), (Cassivi, Lefebvre et al. 2004), (Iyer, Germain et al. 2004), (Auramo, Kauremaa et al. \\
2005), (Eng 2005)
\end{tabular}

These papers analyse the impact of the Internet-enabled supply chain on performance without considering the business conditions and the internal characteristics of the companies. It might be expected that different business conditions and company's characteristics make a different type of Internet collaboration tool more suitable than others as different integration practices are more suitable under different environments. Further research should investigate under which circumstances different Internet-enabled supply chain collaboration tools have a higher impact on performance.

\section{Conclusions}

It has been demonstrated that the Internet can have an important impact on the management of the supply chain and it can improve the competitiveness of firms. The literature review undertaken on the topic has shown that e-SCM has been acknowledged as an outstanding topic in the supply chain literature in the most prestigious Operations Management and Logistics journals, especially after year 2000. However, our literature review has shown that there is a disjointed scattering of research activity that fails to clearly represent what we currently know about the effects of the Internet on SCM and what we still need to learn. In this paper we have attempted (1) to describe the impact that the Internet has on the different supply chain processes, (2) to review the existing literature on the topic, (3) to provide a framework for the analysis of e-SCM, and (4) to identify further lines of research.

Although the literature review is not exhaustive (other management journals should have also been reviewed, such as Marketing and Information Systems journals), it serves as comprehensive base for understanding the impact of the Internet on SCM. Our paper has followed the same methodology as the literature reviews of (Johnson and Whang 2002) and (Gunasekaran and Ngai 2004), but it differs from them on the objectives established and the results achieved. (Johnson and Whang 2002) explored how e-business was changing the supply chain and examined the rapidly evolving research in this area. They 
classified 30 papers into three categories: e-commerce, e-procurement and e-collaboration. They provided a summary of what these papers were covering but they did not identify further lines of research. (Gunasekaran and Ngai 2004) reviewed 114 papers on IT in SCM and elaborated a framework for the development and implementation of IT in SCM. This literature review had the objective of classifying the papers to bring out pertinent factors that would support practitioners in their effort to achieve an IT-enabled SCM. They also provided some lines or further research for academicians. Our paper, as the (Gunasekaran and Ngai 2004) paper, provides a framework to classify the existing research and identifies some lines of further research. One of the key contributions of our paper is that it presents a framework based on the idea that SCM is the management of key business processes, which has been recently adopted by many researchers (see for example, (Romano and Vinelli 2001), (Cagliano, Caniato et al. 2003), (Mills, Schmitz et al. 2004), (Cousins 2005), (Croom 2005), and (Danese, Romano et al. 2006)).

We believe that this paper will be very helpful for practitioners and academicians. Practitioners are provided with some insights regarding which are the main effects of the Internet on SCM and which sources can be consulted in case of being interested in obtaining a deeper knowledge of the impact of the Internet in a specific area (for, example, a practitioner interested in adopting an e-procurement tool can review the papers classified under this topic). Researchers are given a framework that classifies the existing literature. The value of this framework is a tool to help researchers synthesise the volume and breadth on what has been done on e-SCM. Researchers are also given some lines of further research.

We expect that the number of research papers in this area will increase significantly in the next years, given the increased interest in SCM and the Internet by academicians and practitioners. Some directions for further research that we have identified are: to conduct empirical studies about the impact of the Internet on several SCM processes, such as the reverse and the demand management processes which, so far, have been only considered by a couple of authors. Further research should also put more emphasis on conducting empirical studies regarding the implementation of the Internet in the product development process. Another important area of research is the application of decision models and technologies on the Internet and the development of Application Service Providers (ASP) to obtain knowledge for the firms belonging to a supply chain. As more and more firms have high quality and real-time information available, the use of these decision technologies will increase, since they add significant value to the members of a supply chain. Although e-fulfilment has been one of the most covered topics there are still some further lines of research in this area: to study new strategies to respond to the challenge of the last mile problem, and to conduct more empirical studies to explore what companies are doing to respond to this challenge and which are the results of the different actions taken. E-procurement has been the most covered topic, especially the subtopics related with marketplaces and auctions. However, we identified some lines of further research related with this topic: to investigate the benefits and barriers of $\mathrm{B} 2 \mathrm{~B}$ procurement, and to analyse how to strategically segment e-procurement strategies. Finally, despite we found several papers analysing the impact of the Internet on performance, they did not consider business conditions. Different authors suggest that different SCM strategies are more suitable under different business conditions (see for example: (Fisher 1997), (Ramdas and Spekman 2000), (Cigolini, Cozzi et al. 2004) and (Van der Vaart, Giménez et al. 2006)). 
One promising line of further research is to investigate under which circumstances different Internet-enabled supply chain collaboration tools have a higher impact on performance.

\section{References}

Abid, C., S. D'amours, et al. (2004). "Collaborative order management in distributed manufacturing." International Journal of Production Research 42(2): 283-302.

Agarwal, A. and R. Shankar (2003). "Online trust building in e-Enabled Supply Chain." Supply Chain Management: An International Journal 8(4): 324-334.

Agi, M., E. Ballot, et al. (2005). "'100\% EDI-connected suppliers" projects: An empirical investigation of success factors." Journal of Purchasing and Supply Management 11(2-3): 107-115.

Alfaro, J. A., M. J. Alvarez, et al. (2002). Lagging behind versus advancing too fast? Identifying gaps research in Supply Chain. $9^{\text {th }}$ Annual Meeting of the European Operations Management Association (EUROMA), Copenhagen, Denmark.

Alptekinoglu, A. and C. S. Tang (2005). "A model for analyzing multi-channel distribution systems." European Journal of Operational Research 163(3): 802-824.

Auramo, J., J. Kauremaa, et al. (2005). "Benefits of IT in supply chain management: an explorative study of progressive companies." International Journal of Physical Distribution \& Logistics Management 35(2): 82-100.

Bal, J., R. Wilding, et al. (1999). "Virtual teaming in the Agile Supply Chain." The International Journal of Logistics Management 10(2): 71-82.

Bapna, R., P. Goes, et al. (2003). "Analysis and Design of Business-to-Consumer Online Auctions." Management Science 49(1): 85-101.

Barratt, M. and K. Rosdahl (2002). "Exploring business-to-business marketsites." European Journal of Purchasing \& Supply Management 8(2): 111-122.

Bartezzaghi, E. and S. Ronchi (2004). "A portfolio approach in the e-purchasing of materials." Journal of Purchasing and Supply Management 10(3): 117-126.

Bendoly, E. and T. Schoenherr (2005). "ERP system and implementation-process benefits Implications for B2B e-procurement." International Journal of Operations \& Production Management 25(4): 304-319.

Biehl, M. (2005). "Selecting internal and external supply chain functionality: The case of ERP systems versus electronic marketplaces." Journal of Enterprise Information Management 18(4): 441 - 457.

Boyd, S. L., J. E. Hobbs, et al. (2003). "The Impact of Customs on Business to Consumer e-Commerce in Food Products." Supply Chain Management: An International Journal 8(3): 195-200.

Boyer, K. K., R. Hallowell, et al. (2002). "E-services: Operating Strategy -- A Case Study and a Method for Analyzing Operational Benefits." Journal of Operations Management 20(2): 175-189.

Boyer, K. K. and G. T. M. Hult (2005). "Extending the supply chain: Integrating operations and marketing in the online grocery industry." Journal of Operations Management 23(6): 642-661. 
Boyer, K. K. and J. R. Olson (2002). "Drivers of Internet Purchasing Success." Production and Operations Management 11(4): 480-498.

Brenner, W. and V. Hamm (1996). "Information technology for purchasing in a process environment." European Journal of Purchasing \& Supply Management 2(4): 211219.

Bruun, P. and R. N. Mefford (2004). "Lean production and the Internet." International Journal of Production Economics 89(3): 247-260.

Burke, G. J. and A. J. Vakkaria (2002). Supply Chain Management. Internet encyclopedia. H. Biggoli. New York, John Wiley.

Cagliano, R., F. Caniato, et al. (2003). "E-Business Strategy: How companies are shaping their supply chain through the Internet." International Journal of Operations \& Production Management 23(10): 1142-1162.

Cagliano, R., F. Caniato, et al. (2005). "E-Business strategy: How companies are shaping their supply chain through the internet." International Journal of Operations \& Production Management 25(12): 1309-1327.

Calosso, T., M. Cantamessa, et al. (2003). "Production planning and order acceptance in business electronic commerce." International Journal of Production Economics 85: 233-249.

Caputo, A. C., F. Cucchiella, et al. (2005). "An integrated framework for e-supply networks analysis." Supply Chain Management: An International Journal 10(2): 84 $-95$.

Carare, O. and M. Rothkopf (2005). "Slow Dutch Auctions." Management Science 51(3): 365-373.

Carr, S. M. (2003). "Note on Online Auctions with Costly Bid Evaluation." Management Science 49(11): 1521-1529.

Cassivi, L., E. Lefebvre, et al. (2004). "The Impact of E-collaboration Tools on Firms' Performance." The International Journal of Logistics Management 15(1).

Cigolini, R., M. Cozzi, et al. (2004). "A new framework for supply chain management: Conceptual model and empirical test." International Journal of Operations \& Production Management 24(1): 7-41.

Clarke, M. P. (1998). "Virtual Logistics: An Introduction and Overview of the Concepts." International Journal of Physical Distribution \& Logistics Management 28(7): 486507.

Cohen, M., C. B. Kelly, et al. (2001). "Decision Support with Web-Enabled Software." Interfaces 31(2): 109-129.

Cooper, M. C., D. M. Lambert, et al. (1997). "Supply Chain Management: More than a new name for Logistics." The International Journal of Logistics Management 8(1): $1-13$.

Cousins, P. D. (2005). "The alignment pf appropriate firm and supply strategies for competitive advantages." International Journal of Operations \& Production Management 25(5): 403-428.

Croom, S. R. (2000). "The Impact of Web-Based Procurement on the Management of Operating Resources Supply." The Journal of Supply Chain Management 36(1): 413.

Croom, S. R. (2005). "The impact of e-business on supply chain management." International Journal of Operations \& Production Management 25(1): 55-73. 
Crowley, J. A. (1998). "Virtual logistics: Transport in the marketspace." International Journal of Physical Distribution \& Logistics Management 28(7): 547-574.

Croxton, K. L., S. J. García-Dastugue, et al. (2001). "The Supply Chain Management Processes." The International Journal of Logistics Management 12(2): 13-36.

Chan, M. F. S. and W. W. C. Chung (2002). "A framework to develop an enterprise information portal for contract manufacturing." International Journal of Production Economics 75: 113-126.

Cheng, K., P. Y. Pan, et al. (2000). "The Internet as a Tool with Application to Agile Manufacturing: A Web-based Engineering Approach and its Implementation Issues." International Journal of Production Research 38(12): 2743-2759.

Christopher, M. (1998). Logistics and Supply Chain Management: Strategies for reducing cost and improving service. London, Financial Times Pitman Publishing.

Da Silveira, G. J. C. (2003). "Towards a Framework for Operations Management in eCommerce." International Journal of Operations \& Production Management 23(2): 200-212.

Dadzie, K. Q., C. Chelariu, et al. (2005). "Customer service in Internet-enabled logistics supply chain: webside design antecedents and loyalty effects." Journal of Business Logistics 26(1): 53-78.

Danese, P., P. Romano, et al. (2006). "Sequences of improvements in supply networks: case studies from pharmaceuticall industry." International Journal of Operations \& Production Management 26(11): 1199-1222.

Davenport, T. H. and J. D. Brooks (2004). "Enterprise systems and the supply chain." Journal of Enterprise Information Management 17(1): 8 - 19.

de Boer, L., J. Harink, et al. (2002). "A conceptual model for assessing the impact of electronic procurement." European Journal of Purchasing \& Supply Management 8(1): 25-33.

De Burca, S., B. Fynes, et al. (2005). "Strategic technology adoption: extending ERP across the supply chain." Journal of Enterprise Information Management 18(4): 427 $-440$.

Dedrick, J. and K. L. Kraemer (2005). "The Impacts of IT on Firm and Industry Structure: The personal computer industry." California Management Review 47(3): 122-142.

Deeter-Schmelz, D. R., A. Bizzari, et al. (2001). "Business-to-Business Online Purchasing: Suppliers' Impact on Buyers' Adoption and Usage Intent." The Journal of Supply Chain Management 37(1): 4-10.

Delfmann, W., S. Albers, et al. (2002). "The Impact of e-Commerce on Logistics Service Providers." International Journal of Physical Distribution \& Logistics Management 32(3): 203-222.

Deltas, G. and R. Engelbrecht-Wiggans (2005). "Naive Bidding." Management Science 51(3): 328-338.

Dewman, R., M. Freimer, et al. (2000). "Organizing Distribution Channels for Information Goods on the Internet." Management Science 46(4): 483-495.

Ding, M., J. Eliashberg, et al. (2005). "Emotional Bidders--An Analytical and Experimental Examination of Consumers' Behavior in a Priceline-Like Reverse Auction." Management Science 51(3): 352-364.

Disney, S. M., M. M. Naim, et al. (2004). "Assessing the impact of e-business on supply chain dynamics." International Journal of Production Economics 89(2): 109-118. 
Donohue, J. M. and J. B. Fox (2000). "A multiple-method evaluation of journals in Decision and Management Sciences by US academics." Omega 28(1): 17-36.

Easley, R. F. and R. Tenorio (2004). "Jump Bidding Strategies in Internet Auctions." Management Science 50(10): 1407-1419.

Elliman, T. and G. Orange (2000). "E-Commerce to Support Construction Design and Supply-Chain Management: A research Note." International Journal of Physical Distribution \& Logistics Management 30(3/4): 345-360.

Ellinger, A. E., D. F. Lynch, et al. (2003). "B2B e-Commerce: A Content Analytical Assessment of Motor Carrier Websities." Journal of Business Logistics 24(1): 199220.

Ellram, L.-M.-. (1991). "Supply chain managemnet: The industrial organization perspective." International Journal of Physical Distribution \& Logistics Management 21(1): 13-22.

Emiliani, M. L. (2000). "B2B Online Auctions: Key issues for Purchasing Process Improvement." Supply Chain Management: An International Journal 5(4): 176-186.

Emiliani, M. L. and D. J. Stec (2002a). "Realizing Savings from Online Reverse Auctions." Supply Chain Management: An International Journal 7(1): 12-23.

Emiliani, M. L. and D. J. Stec (2002b). "Squaring Online Reverse Auctions with the Caux Round Table Principles for Business." Supply Chain Management: An International Journal 7(2): 92-100.

Emiliani, M. L. and D. J. Stec (2004). "Aerospace parts suppliers' reaction to online reverse auctions." Supply Chain Management: An International Journal 9(2): 139 153.

Eng, T.-Y. (2005). "The Influence of a Firm's Cross-Functional Orientation on Supply Chain Performance." The Journal of Supply Chain Management 41(4): 4-16.

Essig, M. and U. Arnold (2001). "Electronic Procurement in Supply Chain Management: An Information Economics-Based Analysis of Electronic Markets." The Journal of Supply Chain Management 37(4): 43-49.

Finch, B. J. (1999). "Internet Discussions as a Source for Consumer Product Customer Involvement and Quality Information: An Exploratory Study." Journal of Operations Management 17(5): 535-557.

Fisher, M. L. (1997). "What is the right supply chain for your product?" Harvard Business Review March-April: 105-116.

Frohlich, M. T. (2002). "E-Integration in the Supply Chain: Barriers and Performance." Decision Sciences 33(4): 537-556.

Frohlich, M. T. and R. Westbrook (2002). "Demand chain management in manufacturing and services: web-based integration, drivers and performance." Journal of Operations Management 20(6): 729-745.

Gaur, V., A. Giloni, et al. (2005). "Information Sharing in a Supply Chain Under ARMA Demand." Management Science 51(6): 961-969.

Gentry, C. R. (1999). "Reducing the cost of returns." Chain Store Age 75(10): 124-126.

Geoffrion, A. M. and R. Krishnan (2001). "Prospect for Operations Research in the EBusiness Era." Interfaces 31(2): 6-36.

Goh, C. H., C. W. Holsapple, et al. (1997). "Evaluating and classifying POM journal." Journal of Operations Management 15(2): 123-138. 
Golicic, S. L., D. F. Davis, et al. (2002). "The Impact of e-Commerce on Supply Chain Relationships." International Journal of Physical Distribution \& Logistics Management 32(10): 851-871.

Graham, G., B. Burnes, et al. (2004). "The transformation of the music industry supply chain." International Journal of Operations \& Production Management 24(11): 1087-1103.

Graham, G. and G. Hardaker (2000). "Supply-Chain Management across the Internet." International Journal of Physical Distribution \& Logistics Management 30(3/4): 286-295.

Granot, D. and G. Sošic (2005). "Formation of Alliances in Internet-Based Supply Exchanges." Management Science 51(1).

Greis, N. P. and J. D. Kasarda (1997). "Enterprise Logistics in the Information Era." California Management Review 39(4): 55-78.

Grieger, M. (2003). "Electronic Marketplaces: A literature review and a call for supply chain management review." European Journal of Operational Research 144: 280294.

Gudmundsson, S. V. and R. Walczuck (1999). "The development of Electronic Markets in Logistics." The International Journal of Logistics Management 10(2): 99-113.

Gunasekaran, A., A. H.B. Marri, et al. (2002). "E-commerce and Its Impact on Operations Management." International Journal of Production Economics 75(1/2): 185-198.

Gunasekaran, A. and E. W. T. Ngai (2004). "Information systems in supply chain integration and management." European Journal of Operational Research 159(2): 269-295.

Gunluk, O., L. Ladányi, et al. (2005). "A Branch-and-Price Algorithm and New Test Problems for Spectrum Auctions." Management Science 51(3): 391-406.

Gurãu, C., A. Ranchhod, et al. (2001). "Internet transactions and physical logistics: conflict or complementary?" Logistics Information Management 14(1/2): 33-43.

Harland, C. M. (1996). "Supply Chain Management: relationships, Chains and Networks." British Journal of Management 7(Special Issue): S63-S80.

Hayes, J. and P. Finnegan (2005). "Assessing the of potential of e-business models: towards a framework for assisting decision-makers." European Journal of Operational Research 160(2): 365-379.

Hazra, J., B. Mahadevan, et al. (2004). "Capacity allocation among multiple suppliers in an electronic market." Production and Operations Management 13(2): 161-170.

Hewitt, F. (1994). "Supply Chain Redesign." The International Journal of Logistics Management 5(2): 1-9.

Hohner, G., J. Rich, et al. (2003). "Combinatorial and Quantity-Discount Procurement Auctions Benefit Mars, Incorporated and Its Suppliers." Interfaces 33(1): 23-35.

Houlihan, J. (1984). Supply Chain Management. 19th International Technical Conference, BPICS.

Iyer, K. N. S., R. Germain, et al. (2004). "Supply chain B2B e-commerce and time-based delivery performance." International Journal of Physical Distribution \& Logistics Management 34(8): 645-661.

James, M., R. Grosvenor, et al. (2004). "e-Distribution: Internet-based management of a merchandiser supply chain." Supply Chain Management: An International Journal 9(1): 7 - 15. 
Jap, S. and J. J. Mohr (2002). "Leveraging Internet Technologies in B2B Relationships." California Management Review 44(4): 24-38.

Johnson, M. E. and S. Whang (2002). "E-business and Supply Chain Management: An Overview and Framework." Production and Operations Management 11(4): 413423.

Joo, Y.-B. and Y.-G. Y.-G. Kim (2004). "Determinants of corporate adoption of eMarketplace: an innovation theory perspective." Journal of Purchasing and Supply Management 10(2): 89-101.

Jouenne, T. (2000). "HENKEL-EROSKI CPFR Pilot Case Study." CPFR White Paper (www.cpfr.org).

Kämäräinen, V. (2001). "The Reception Box Impact on Home Delivery Efficiency in the e-Grocery Business." International Journal of Physical Distribution \& Logistics Management 31(6): 414-426.

Kaplan, S. and M. Sawhney (2000). "E-Hubs: The New B2B Marketplaces." Harvard Business Review: 97-103.

Kaufmann, L. and C. R. Carter (2002). "International Supply Management Systems; The Impact of Price vs. Non-Price Driven Motives in the United States and Germany." The Journal of Supply Chain Management 38(3): 4-17.

Keenan, F. and S. Ante (2002). "The New Teamwork." Business Week.

Kehoe, D. F. and N. J. Boughton (2001a). "New Paradigms in Planning and Control across Manufacturing Supply Chain." International Journal of Operations \& Production Management 21(5/6): 582-593.

Kehoe, D. F. and N. J. Boughton (2001b). "Internet Based Supply Chain management: A Classification of Approaches to Manufacturing Planning and Control." International Journal of Operations \& Production Management 21(4): 516-524.

Kelleher, G., A. El-Rahalibi, et al. (2003). "Scheduling for intermodal transport." Logistics Information Management 16(5): 363-372.

Keskinocak, P. and S. R. Tayur (2001). "Quantitative analysis for Internet-Enabled Supply Chains." Interfaces 31(2): 70-89.

Kevin Chiang, W.-y. and G. E. Monahan (2005). "Managing inventories in a two-echelon dual-channel supply chain." European Journal of Operational Research 162(2): 325-341.

Kleindorfer, P. R. and D. J. Wu (2003). "Integrating Long- and Short-Term Contracting via Business-to-Business Exchanges for Capital Intensive Industries." Management Science 49(11): 1597-1615.

Knudsen, D. (2003). "Aligning Corporate Strategy, Procurement Strategy and eProcurement Tools." International Journal of Physical Distribution \& Logistics Management 33(8): 720-734.

Ko, C. S., T. Kim, et al. (2001). "External Partner Selection Using Tabu Search Heuristics in Distributed Manufacturing." International Journal of Production Research 39(17): 3959-3974.

Kotzab, H. and M. Madlberger (2001). "European retailing in e-Transition? An Empirical Evaluation of Web-Based Reatiling - Indications from Austria." International Journal of Physical Distribution \& Logistics Management 31(6): 440-462. 
Larson, P. D., P. Carr, et al. (2005). "SCM Involving Small Versus Large Suppliers: Relational Exchange and Electronic Communication Media." The Journal of Supply Chain Management 41(1): 18-29.

Lee, H. L. (2002). "Aligning Supply Chain Strategies with Product Uncertainties." California Management Review 44(3): 105-119.

Lee, H. L. and S. Whang (2001). "Winning the last Mile of E-Commerce." MIT Sloan Management Review 42(4): 54-62.

Lee, H. L. and S. Whang (2002). "The Impact of Secondary Market on the Supply Chain." Management Science 48(6): 719-731.

Lee, Y. M. and E. J. Chen (2002). "BASF Uses Framework for Developing Web-based Production-Planning-Optimization Tools." Interfaces 32(6): 15-24.

Lewis, G. J., G. Graham, et al. (2005). "Evaluating the impact of the internet on barriers to entry in the music industry." Supply Chain Management: An International Journal 10(5): 349 - 356.

Lewis, I. and A. Talalayevsky (2004). "Improving the interorganizational supply chain through optimization of information flows." Journal of Enterprise Information Management 17(3): 229 - 237.

Lyons, A. C., A. E. Coronado Mondragon, et al. (2005). "Prototyping an information system's requirements architecture for customer-driven, supply-chain operations." International Journal of Production Research 43(20): 4289-4319.

Mahadevan, B. (2000). "Business Models for Internet-Based e-commerce: An anatomy." California Management Review 42(4): 55-69.

Mahadevan, B. (2003). "Making Sense of Emerging Market Structures in B2B ecommerce." California Management Review 46(1): 86-100.

Marinus, R. and B. M. De Koster (2002). "Distribution Structures for Food Home Shopping." International Journal of Physical Distribution \& Logistics Management 32(5): 362-380.

McGuffog, T. and N. Wadsley (1999). "The General Principles of Value Chain Management." Supply Chain Management: An International Journal 4(5): 218-225.

Mclvor, R. and P. Humphreys (2004). "The implications of electronic B2B intermediaries for the buyer-supplier interface." International Journal of Operations \& Production Management 24(3): 241-269.

Metty, T., R. Harlan, et al. (2005). "Reinventing the Supplier Negotiation Process at Motorola." Interfaces 35(1).

Meyer, H. (1999). "Many happy returns." The Journal of Business Strategy 20(4): 27-31.

Mills, J., J. Schmitz, et al. (2004). "A strategic review of "supply networks"." International Journal of Operations \& Production Management 24(10): 1012-1036.

Min, H. and W. P. Galle (1999). "E-Commerce Usage in B2B Purchasing." International Journal of Operations \& Production Management 19(9): 909-921.

Mondal, S. and M. K. Tiwari (2003). "Formulation of Mobile Agents for Integration of Supply Chain Using the KLAIM concept." International Journal of Production Research 41(1): 97-120.

Muffatto, M. and A. Payaro (2004). "Implementation of e-procurement and e-fulfillment processes: A comparison of cases in the motorcycle industries." International Journal of Production Economics 89(3). 
Mukhopadhyay, S. K. and R. Setoputro (2004). "Reverse logistics in e-business: Optimal price and return policy." International Journal of Physical Distribution \& Logistics Management 34(1): 70-88.

Nagurney, A., J. Cruz, et al. (2005). "Supply chain networks, electronic commerce, and supply side and demand side risk." European Journal of Operational Research 164(1): 120-142.

Nair, A. (2005). "Emerging internet-enabled auction mechanisms in supply chain." Supply Chain Management: An International Journal 10(3): 162 - 168.

O'Keefe, M. (2001a). "Building Intellectual Capital in the Supply Chain - The Role of eCommerce." Supply Chain Management: An International Journal 6(4): 148-151.

O'Keeffe, M. (2001b). "Myths and Realities of e-Commerce in the Perishable Foods Industries: Unleashing the Power of Reputation and Relationship Assets." Supply Chain Management: An International Journal 6(1): 12-15.

Oliver, R. K. and m. D. Webber (1992). Supply-chain management: logistics catches up with strategy. Logistics: The Strategic Issues. M. Christopher. London, Chapman \& Hall: 63-75.

Olson, J. R. and K. K. Boyer (2003). "Factors influencing the utilization of Internet purchasing in small organizations." Journal of Operations Management 21: 225245.

Ordanini, A. (2005). "The Effects of Participation on B2B Exchanges: A Resource-Based View." California Management Review 47(2): 97-113.

Pannirselvam, G. P., L. A. Ferguson, et al. (1999). "Operations Management Research: an update for the 1990s." Journal of Operations Management 18: 95-112.

Papathanassiou, E., D. Kardaras, et al. (2003). "Management context and impact of ecommerece in the Greek food industries." Logistics Information Management 16(2): 134-144.

Parente, D. H., R. Venkataraman, et al. (2004). "A conceptual research framework for analyzing online auctions in a B2B environment." Supply Chain Management: An International Journal 9(4): 287 - 294.

Peleg, B., H. L. Lee, et al. (2002). "Short-Term e-procurement strategies versus LongTerm contracts." Production and Operations Management 11(4): 458-479.

Pinker, E. J., A. Seidmann, et al. (2003). "Managing Online Auctions: Current Business and Research Issues." Management Science 49(11): 1457-1485.

Piramuthu, S. (2005). "Knowledge-based framework for automated dynamic supply chain configuration." European Journal of Operational Research 165(1): 219-230.

Power, D. (2005). "Determinants of business-to-business e-commerce implementation and performance: a structural model." Supply Chain Management: An International Journal 10(2): 96 - 113.

Prasad, S. and S. Babbar (2000). "International Operations Management Research." Journal of Operations Management 18: 209-247.

Punakivi, M., H. Yrjölä, et al. (2001). "Solving the Last Mile issue: Reception Box or Delivery Box?" International Journal of Physical Distribution \& Logistics Management 31(6): 427-439.

Rabinovich, E. (2004). "Internet retailing Intermediation: A Multilevel Analisys of Inventory Liquity Ans Fulfillment Guarantees." Journal of Business Logistics 25(2): 139-169. 
Rabinovich, E. (2005). "Consumner direct fulfillment performance in Internet retailing: emergency transshipments and demand dispersion." Journal of Business Logistics 26(1): 79-112.

Rabinovich, E. and J. P. Bailey (2004). "Physical distribution service quality in Internet retailing: service pricing, transaction attributes, and firm attributes." Journal of Operations Management 21(6): 651-672.

Rabinovich, E. and P. T. Evers (2003). "Product fulfillment in supply chains supporting Internet-retailing operations." Journal of Business Logistics 24(2): 205-236.

Rae-Smith, J. B. and A. E. Ellinger (2002). "Insights from the Introduction of an Online Logistics Service System." Supply Chain Management: An International Journal 7(1): 5-11.

Ramdas, K. and R. E. Spekman (2000). "Chain or Chackles: understanding what drives supply-chain performance." Interfaces 30(4): 3-21.

Richard, P. J. and T. M. Devinney (2005). "Modular Strategies: B2B Technology and Architectural Knowledge." California Management Review 47(4): 86-113.

Roberts, B. and M. Mackay (1998). "IT supporting supplier relationships: The role of electronic commerce." European Journal of Purchasing \& Supply Management 4(23): $175-184$.

Robinson, E. P., F. Sahin, et al. (2005). "The Impact of E-Replenishment Strategy on Make-to-Order Supply Chain Performance." Decision Sciences 36(1): 33-64.

Rogers, D. S. and R. S. Tibben-Lemke (1999). Going Backwards: Reverse Logistics Trends and Practices. Pittsburgh, PA, Reverse Logistics Executive Council Press.

Romano, P. and A. Vinelli (2001). "Quality management in a supply chain perpective: Startegic and operative choices ina a textile-apparel network." International Journal of Operations \& Production Management 21(4): 446-460.

Rubiano Ovalle, O. and A. Crespo Marquez (2003). "The effectiveness of using ecollaboration tools in the supply chain: an assessment study with system dynamics." Journal of Purchasing and Supply Management 9(4): 151-163.

Saeed, K. A., M. K. Malhotra, et al. (2005). "Examining the Impact of Interorganizational Systems on Process Efficiency and Sourcing Leverage in Buyer-Supplier Dyads." Decision Sciences 36(3): 365-396.

Sarkis, J., L. M. Meade, et al. (2004). "E-logistics and the natural environment." Supply Chain Management: An International Journal 9(4): 303 - 312.

Sarkis, J. and R. P. Sundarraj (2002). "Evolution of Broking: Paradigms in E-commerce Enabled Manufacturing." International Journal of Production Economics 75(1/2): 21-32.

Sarkis, J. and S. Talluri (2004). "Evaluating and selecting e-commerce software and communication systems for a supply chain." European Journal of Operational Research 159(2): 318-329.

Scott, C. H. and J. E. J. E. Scott (2004). "On models for the operation of a class of electronic marketplaces." Omega 32(5): 373-383.

Scullin, S. S., J. Fjermestad, et al. (2004). "E-relationship marketing: changes in traditional marketing as an outcome of electronic customer relationship management." Journal of Enterprise Information Management 17(6): 410 - 415.

Seifert, R. W., U. W. Thonemann, et al. (2004). "Optimal procurement strategies for online spot markets." European Journal of Operational Research 152(3): 781-799. 
Shen, W., R. Kremer, et al. (2003). "A Collaborative Agent-based Infrastructure for Internet-enabled Collaborative Enterprises." International Journal of Production Research 41(8): 1621-1639.

Småros, J., J. Holmström, et al. (2000). "New service opportunities in the e-grocery business." The International Journal of Logistics Management 11(1): 61-73.

Smart, A. (2005). "Exploring supply chain opportunities in the UK utilities sector and the supporting role of eMarketplaces." Supply Chain Management: An International Journal 10(4): 264 - 271.

Snir, E. M. and L. M. Hitt (2003). "Costly Bidding in Online Markets for IT Services." Management Science 49(11): 1504-1520.

Sodhi, M. S. (2001). "Applications and opportunities for Operations Research in InternetEnabled Supply Chains and Electronic Marketplaces." Interfaces 31(2): 56-69.

Soteriou, A. C., G. C. Hadjinicola, et al. (1999). "Assessing Production and Operations Management related journals: The European perspective." Journal of Operations Management 17(2): 225-238.

Soto, J. P. and H. R. Lourenço (2002). A Recoverable Production Planning Model. Departmet of Economics and Business. Barcelona, Universitat Pompeu Fabra.

Sparks, L. and B. A. Wagner (2003). "Retail Exchanges: A Research Agenda." Supply Chain Management: An International Journal 8(1): 17-25.

Spengler, T. and M. Schröter (2003). "Strategic Management of Spare Parts in ClosedLoop Supply Chains -- A System Dynamics Approach." Interfaces 33(6): 7-17.

Starr, M. K. (2003). "Application of POM to e-Business: B2C e-Shopping." International Journal of Operations \& Production Management 23(1): 105-124.

Stefansson, G. (2002). "Business-to-business data sharing: A source for integration of supply chain." International Journal of Production Economics 75: 135-146.

Swaminathan, J. M. and S. R. Tayur (2003). "Models for Supply Chains in E-Business." Management Science 49(10): 1387-1406.

Talluri, S. and G. L. Ragazt (2004). "Multi Attribute Reverse Auctions in B2B Exchanges: A framework for Design and Implementation." The Journal of Supply Chain Management 40(1): 52-60.

Tatsiopoulos, I. P., S. T. Ponis, et al. (2002). "Realization of the Virtual Enterprise Paradigm in the Clothing Industry through E-business Technology." Production and Operations Management 11(4): 516-530.

Teich, J. E., H. Wallenius, et al. (2004). "Emerging multiple issue e-auctions." European Journal of Operational Research 159(1): 1-16.

Themistocleous, M., Z. Irani, et al. (2004). "Evaluating the integration of supply chain information systems: A case study." European Journal of Operational Research 159(2): 393-405.

Thirumalai, S. and K. K. Sinha (2005). "Customer satisfaction with order fulfillment in retail supply chains: implications of product type in electronic B2C transactions." Journal of Operations Management 23(3-4): 291-303.

Tsay, A. A. and N. Agrawal (2004). "Channel conflict and coordination in the E-commerce age." Production and Operations Management 13(1): 93-110.

Tsikriktsis, N., G. Lanzolla, et al. (2004). "Adoption of e-processes by service firms: An empirical study of antecedents." Production and Operations Management 13(3): 216-229. 
Tucker, D. and L. Jones (2000). "Leveraging the Power of the Internet for Optimal Supplier Sourcing." International Journal of Physical Distribution \& Logistics Management 30(3/4): 255-267.

Turowski, K. (2002). "Agent-based e-commerce in case of mass customization." International Journal of Production Economics 75: 69-81.

Tyan, J. C., F. Wang, et al. (2003). "An Evaluation of Freight Consolidation Policies in Global Third Party Logistics." Omega 31(1): 55-62.

Upton, D. M. and A. McAfee (1996). "The real virtual factory." Harvard Business Review: 123-133.

Van der Vaart, T., C. Giménez, et al. (2006). Supply chain integration and performance: the impact of business conditions. 13th EUROMA Annual International Conference.

Van Hoek, R. I. (2001). "E-Supply Chains - Virtually Non-Existing." Supply Chain Management: An International Journal 6(1): 21-28.

van Nunen, J. A. E. E. and R. A. Zuidwijk (2004). "E-Enabled Closed-Loop Supply Chains." California Management Review 46(2): 40-54.

Vannieuwenhuyse, B., L. Gelders, et al. (2003). "An online decision support system for transportation mode choice." Logistics Information Management 16(2): 125-133.

Vastag, G. and F. Montabon (2002). "Journal characteristics, ranking and social acculturation in Operations Management." Omega 30(2): 109-126.

Vlachos, D. and R. Dekker (2003). "Return Handling Options and Order Quantities for Single Period Products." European Journal of Operational Research 151(1): 38-53.

Vokurka, R. J. (1996). "The relative importance of journals in Operations Management research: A citation analysis." Journal of Operations Management 14(4): 345-355.

Wang, C. X. and M. Benaroch (2004). "Supply chain coordination in buyer centric B2B electronic markets." International Journal of Production Economics 92(2): 113-124.

White, A. and E. M. Daniel (2004). "The impact of e-marketplaces on dyadic buyersupplier relationships: evidence from the healthcare sector." Journal of Enterprise Information Management 17(6): 441 - 453.

Wilson, T. P. and W. R. Clarke (1998). "Food Safety and Traceability in the Agricultural Supply Chain: Using the Internet to Deliver Traceability." Supply Chain Management: An International Journal 3(3): 127-133.

Williams, L. R., T. L. Esper, et al. (2002). "The e-Supply Chain: Its Impact on the Current and Future Structure of Strategic Alliances, Partnerships and Logistics Leadership." International Journal of Physical Distribution \& Logistics Management 32(8): 703719.

Wise, R. and D. Morrison (2000). "Beyond the Exchange: The future of B2B." Harvard Business Review: 86-96.

Wu, D. J. and P. R. Kleindorfer (2005). "Competitive Options, Supply Contracting, and Electronic Markets." Management Science 51(3).

Xie, S. Q., P. L. Tu, et al. (2001). "A WWW-based Integrated Product Development Platform for Sheet Metal Parts Intelligent Concurrent Design and Manufacturing." International Journal of Production Research 39(17): 3829-3853.

Xie, S. Q., Y. L. Tu, et al. (2003). "Rapid One-of-a-kind Product Development Via the Internet: A Literature Review of the State-of-the-art and a Proposed Platform." International Journal of Production Research 41(18): 4257-4299. 
Xie, S. Q., X. Xu, et al. (2005). "A reconfigurable platform in support of one-of-a-kind product development." International Journal of Production Research 43(9): 18891910.

Xie, Y. and G. Salvendy (2003). "Agent-based Features for CAD Browsers to Foster Engineering Collaboration over the Internet." International Journal of Production Research 41(16): 3809-3830.

Xiong, M., S. B. Tor, et al. (2003). "A web-enhanced Dynamic BOM-based Avalilable-topromise System." International Journal of Production Economics 84(2): 133-148.

Yeh, Y.-P. (2005). "Identification of factors affecting continuity of cooperative electronic supply chain relationships: empirical case of the Taiwanese motor industry." Supply Chain Management: An International Journal 10(4): 327 - 335.

Yoo, S. B. and Y. Kim (2002). "Web-based Knowledge Management for Sharing Product Data in Virtual Enterprises." International Journal of Production Economics 75(1/2): 173-184.

Yrjölä, H. (2001). "Physical Distribution Considerations for e-Grocery Shopping." International Journal of Physical Distribution \& Logistics Management 31(10): 746-761.

Zhu, K. (2004). "Information Transparency of Business-to-Business Electronic Markets: A Game-Theoretic Analysis." Management Science 50(5): 670-685. 
Table IA. Papers classified per topic and research methodology

\begin{tabular}{|c|c|c|c|}
\hline \multirow{2}{*}{ TOPIC } & \multicolumn{3}{|c|}{ Empirical } \\
\hline & Case Study & Survey & Web scan \\
\hline Customer relationship management & (Boyer, Hallowell et al. 2002) & (Tsikriktsis, Lanzolla et al. 2004) & \\
\hline Customer service management & (Rae-Smith and Ellinger 2002) & (Papathanassiou, Kardaras et al. 2003) & (Ellinger, Lynch et al. 2003) \\
\hline \multicolumn{4}{|l|}{ Demand management } \\
\hline e-fulfilment & (Da Silveira 2003; Starr 2003) & $\begin{array}{l}\text { (Marinus and De Koster 2002; Vannieuwenhuyse, } \\
\text { Gelders et al. 2003; Rabinovich 2004; Rabinovich and } \\
\text { Bailey 2004; Boyer and Hult 2005; Dadzie, Chelariu et } \\
\text { al. 2005; Rabinovich 2005; Thirumalai and Sinha 2005) }\end{array}$ & $\begin{array}{l}\text { (Gurãu, Ranchhod et al. 2001; Kotzab and } \\
\text { Madlberger 2001) }\end{array}$ \\
\hline Manufacturing flow management & (Bruun and Mefford 2004) & & \\
\hline e-procurement & (Kaufmann and Carter 2002; Smart 2005) & $\begin{array}{l}\text { (Min and Galle 1999; Croom 2000; Deeter-Schmelz, } \\
\text { Bizzari et al. 2001; Boyer and Olson 2002; Olson and } \\
\text { Boyer 2003; Bartezzaghi and Ronchi 2004; Emiliani } \\
\text { and Stec 2004; Joo and Kim 2004; Ordanini 2005; } \\
\text { Saeed, Malhotra et al. 2005) }\end{array}$ & (Mahadevan 2003) \\
\hline $\begin{array}{l}\text { Product development and } \\
\text { commercialization }\end{array}$ & (Finch 1999; Xie, Xu et al. 2005) & & \\
\hline Reverse logistics and returns & (van Nunen and Zuidwijk 2004) & & \\
\hline Several supply chain processes & (Muffatto and Payaro 2004; Croom 2005) & $\begin{array}{l}\text { (Cagliano, Caniato et al. 2003; Cagliano, Caniato et al. } \\
\text { 2005) }\end{array}$ & \\
\hline Supply chain relationships & $\begin{array}{l}\text { (Roberts and Mackay 1998; Golicic, Davis et al. } \\
\text { 2002; White and Daniel 2004) }\end{array}$ & (Yeh 2005) & \\
\hline Information flows & $\begin{array}{l}\text { (Chan and Chung 2002; Stefansson 2002; } \\
\text { Tatsiopoulos, Ponis et al. 2002; Mondal and Tiwari } \\
\text { 2003; James, Grosvenor et al. 2004; Themistocleous, } \\
\text { Irani et al. 2004; Bendoly and Schoenherr 2005; } \\
\text { Biehl 2005; De Burca, Fynes et al. 2005; Lyons, } \\
\text { Coronado Mondragon et al. 2005) }\end{array}$ & $\begin{array}{l}\text { (Bal, Wilding et al. 1999; Agi, Ballot et al. 2005; } \\
\text { Larson, Carr et al. 2005; Power 2005) }\end{array}$ & \\
\hline \multicolumn{4}{|l|}{ Planning \& optimisation } \\
\hline $\begin{array}{l}\text { Industry structure and competitive } \\
\text { challenges }\end{array}$ & $\begin{array}{l}\text { (Graham, Burnes et al. 2004; Mclvor and } \\
\text { Humphreys 2004; Dedrick and Kraemer 2005; } \\
\text { Richard and Devinney 2005) }\end{array}$ & & \\
\hline Impact on performance & (Cassivi, Lefebvre et al. 2004) & $\begin{array}{l}\text { (Frohlich 2002; Frohlich and Westbrook 2002; Iyer, } \\
\text { Germain et al. 2004; Auramo, Kauremaa et al. 2005; } \\
\text { Eng 2005) }\end{array}$ & \\
\hline
\end{tabular}




\begin{tabular}{|c|c|c|c|}
\hline TOPIC & Literature Review & Conceptual and frameworks & Decision Models \\
\hline Customer relationship management & & (Småros, Holmström et al. 2000; Scullin, Fjermestad et al. 2004) & \\
\hline \multicolumn{4}{|l|}{ Customer service management } \\
\hline Demand management & & (McGuffog and Wadsley 1999) & \\
\hline e-fulfilment & & $\begin{array}{l}\text { (Crowley 1998; Yrjölä 2001; Delfmann, Albers et al. 2002; Lee 2002; } \\
\text { Boyd, Hobbs et al. 2003) }\end{array}$ & $\begin{array}{l}\text { (Dewman, Freimer et al. 2000; Kämäräinen 2001; } \\
\text { Punakivi, Yrjölä et al. 2001; Kelleher, El-Rahalibi et } \\
\text { al. 2003; Rabinovich and Evers 2003; Tyan, Wang } \\
\text { et al. 2003; Tsay and Agrawal 2004; Alptekinoglu } \\
\text { and Tang 2005; Kevin Chiang and Monahan 2005; } \\
\text { Nagurney, Cruz et al. 2005; Piramuthu 2005) }\end{array}$ \\
\hline Manufacturing flow management & & (Kehoe and Boughton 2001a; Kehoe and Boughton 2001b) & $\begin{array}{l}\text { (Ko, Kim et al. 2001; Xiong, Tor et al. 2003; Abid, } \\
\text { D'amours et al. 2004) }\end{array}$ \\
\hline e-procurement & $\begin{array}{l}\text { (Grieger 2003; Kleindorfer and Wu } \\
\text { 2003; Teich, Wallenius et al. 2004) }\end{array}$ & $\begin{array}{l}\text { (Brenner and Hamm 1996; Gudmundsson and Walczuck 1999; Emiliani } \\
\text { 2000; Kaplan and Sawhney 2000; Mahadevan 2000; Tucker and Jones } \\
\text { 2000; Wise and Morrison 2000; Essig and Arnold 2001; Barratt and } \\
\text { Rosdahl 2002; de Boer, Harink et al. 2002; Emiliani and Stec 2002a; } \\
\text { Emiliani and Stec 2002b; Knudsen 2003; Sparks and Wagner 2003; } \\
\text { Parente, Venkataraman et al. 2004; Talluri and Ragazt 2004) }\end{array}$ & $\begin{array}{l}\text { (Lee and Whang 2002; Peleg, Lee et al. 2002; } \\
\text { Bapna, Goes et al. 2003; Calosso, Cantamessa et al. } \\
\text { 2003; Carr 2003; Hohner, Rich et al. 2003; Pinker, } \\
\text { Seidmann et al. 2003; Snir and Hitt 2003; Easley } \\
\text { and Tenorio 2004; Hazra, Mahadevan et al. 2004; } \\
\text { Scott and Scott 2004; Seifert, Thonemann et al. } \\
\text { 2004; Wang and Benaroch 2004; Carare and } \\
\text { Rothkopf 2005; Deltas and Engelbrecht-Wiggans } \\
\text { 2005; Ding, Eliashberg et al. 2005; Granot and Sošic } \\
\text { 2005; Gunluk, Ladányi et al. 2005; Metty, Harlan et } \\
\text { al. 2005; Wu and Kleindorfer 2005) }\end{array}$ \\
\hline $\begin{array}{l}\text { Product development and } \\
\text { commercialization }\end{array}$ & (Xie, Tu et al. 2003) & (Elliman and Orange 2000) & $\begin{array}{l}\text { (Cheng, Pan et al. 2000; Xie, Tu et al. 2001; Xie and } \\
\text { Salvendy 2003) }\end{array}$ \\
\hline Reverse logistics and returns & & & $\begin{array}{l}\text { (Spengler and Schröter 2003; Vlachos and Dekker } \\
\text { 2003; Mukhopadhyay and Setoputro 2004) }\end{array}$ \\
\hline Several supply chain processes & $\begin{array}{l}\text { (Johnson and Whang 2002; } \\
\text { Gunasekaran and Ngai 2004) }\end{array}$ & (Gunasekaran, H.B. Marri et al. 2002; Sarkis, Meade et al. 2004) & (Robinson, Sahin et al. 2005) \\
\hline Supply chain relationships & & $\begin{array}{l}\text { (O'Keefe 2001a; O'Keeffe 2001b; Jap and Mohr 2002; Williams, Esper } \\
\text { et al. 2002; Caputo, Cucchiella et al. 2005; Nair 2005) }\end{array}$ & (Agarwal and Shankar 2003) \\
\hline Information flows & & $\begin{array}{l}\text { (Upton and McAfee 1996; Greis and Kasarda 1997; Wilson and Clarke } \\
\text { 1998; Van Hoek 2001; Sarkis and Sundarraj 2002; Turowski 2002; } \\
\text { Davenport and Brooks 2004; Lewis and Talalayevsky 2004; Hayes and } \\
\text { Finnegan 2005) }\end{array}$ & $\begin{array}{l}\text { (Yoo and Kim 2002; Disney, Naim et al. 2004; } \\
\text { Sarkis and Talluri 2004; Zhu 2004; Gaur, Giloni et } \\
\text { al. 2005) }\end{array}$ \\
\hline Planning \& optimisation & (Swaminathan and Tayur 2003) & $\begin{array}{l}\text { (Geoffrion and Krishnan 2001; Keskinocak and Tayur 2001; Sodhi } \\
\text { 2001) }\end{array}$ & $\begin{array}{l}\text { (Cohen, Kelly et al. 2001; Lee and Chen 2002; Shen, } \\
\text { Kremer et al. 2003) }\end{array}$ \\
\hline $\begin{array}{l}\text { Industry structure and competitive } \\
\text { challenges }\end{array}$ & & (Clarke 1998; Graham and Hardaker 2000; Lewis, Graham et al. 2005) & \\
\hline Impact on performance & & & (Rubiano Ovalle and Crespo Marquez 2003) \\
\hline
\end{tabular}

